NBER WORKING PAPER SERIES

\title{
HOW DO THE U.S AND CANADIAN SOCIAL SAFETY NETS COMPARE FOR WOMEN AND CHILDREN?
}

\author{
Hilary Hoynes \\ Mark Stabile \\ Working Paper 23380 \\ http://www.nber.org/papers/w23380 \\ NATIONAL BUREAU OF ECONOMIC RESEARCH \\ 1050 Massachusetts Avenue \\ Cambridge, MA 02138 \\ May 2017
}

This paper was prepared for the NBER conference "Public Policies in Canada and the United States" held October 27-28, 2016 in Ottawa. We thank Dorian Carloni, Diogo Machado, Melissa Pogue, Krista Ruffini, and Darian Woods for excellent research assistance and conference participants for helpful suggestions. Stabile acknowledges support from the Martin Prosperity Institute where he is a Fellow. The views expressed herein are those of the authors and do not necessarily reflect the views of the National Bureau of Economic Research.

NBER working papers are circulated for discussion and comment purposes. They have not been peer-reviewed or been subject to the review by the NBER Board of Directors that accompanies official NBER publications.

(C) 2017 by Hilary Hoynes and Mark Stabile. All rights reserved. Short sections of text, not to exceed two paragraphs, may be quoted without explicit permission provided that full credit, including (๑) notice, is given to the source. 
How do the U.S and Canadian Social Safety Nets Compare for Women and Children?

Hilary Hoynes and Mark Stabile

NBER Working Paper No. 23380

May 2017

JEL No. H24,I38

\begin{abstract}
$\underline{\text { ABSTRACT }}$
The past 25 years has seen substantial change in the social safety nets for families with children in the US and Canada. Both countries have moved away from cash welfare but the US has done so relying more exclusively on inwork benefits with work requirements. This paper examines this evolution across the two countries and examines the effects on employment and poverty. In particular, we focus on the two largest programs over this period: the U.S. EITC and the Canadian NCB/CCTB. In light of these policy changes, we examine trends in employment and poverty of the most affected families -- single mothers with less than a college degree -- across the two countries. We find that employment improved substantially in both countries, absolutely and relative to a control group of single women without children. The cross-country differences in relative trends are mainly explained by differences in the labor market conditions. Poverty rates for single mothers also declined in both countries with more of the decline coming through market income in the U.S. and benefit income in Canada.
\end{abstract}

Hilary Hoynes

Richard \& Rhoda Goldman School of Public Policy

University of California, Berkeley

2607 Hearst Avenue

Berkeley, CA 94720-7320

and NBER

hoynes@berkeley.edu

Mark Stabile

INSEAD

Europe Campus

Boulevard de Constance

77305 Fontainebleau

France

mark.stabile@insead.edu 


\section{Introduction}

The past 25 years has been a period of active policy reform in the social safety nets of both the United States and Canada. Perhaps more than any other area of social policy, programs in both countries aimed at low-income families and children have evolved from their pre-1990 form. In 1990 in the United States federal cash welfare was an entitlement, the Earned Income Tax Credit was a modest program, and there was no Child Tax Credit. Additionally, public health insurance for low income families with children was largely limited to those receiving cash welfare. In Canada there was no National Child Benefit, Canada Child Tax Benefit, or Working Income Tax Benefit, and most benefits took the form of cash welfare. Today, the U.S. Earned Income Tax Credit and the Canadian National Child Benefit (and its successor the Canadian Child Benefit) provide the backbone of the social safety net for low income families with children in both countries. These changes to the social safety net in the two countries have evolved in ways that are similar to one another, and yet there are notable differences between programs that reflect distinctly different policy goals. The purpose of this paper is to examine this evolution across the two countries, and to provide and review evidence on how the programs have fared in achieving their goals.

This paper focuses on single women of working age with children and the social safety net that is provided to this group. Changes in labor supply and poverty for men and for those without children over this period also provides for interesting study and while not the subject of this paper we do provide some evidence on the changes in employment and poverty for women without children as a comparison group. However, our focus is on single women with children for several reasons. First, as we describe below, the major 
changes in the social safety net over the past 25 years have focused on providing benefits to low-income families; less assistance is available, and less change has occurred, for single individuals. Second, a significant amount of research in the past two decades has focused on the relationship between these safety net programs and the labor market performance of women as well as the educational and health outcomes for children. Third, while many of the current programs and policies are aimed at children, independent of family structure, we focus on single mothers because of their greater disadvantage. Finally, while these programs have increased in generosity over the past 25 years, a good deal of poverty in both countries remains concentrated among this group.

Overall we find that the introduction and evolution of the EITC and NCB have had positive effects on labor force attachment and poverty. Our findings suggest that employment for single mothers without a college degree has increased over this period in both countries and has caught-up to employment for childless women. While employment for single women (with and without children) declined in the U.S. and not Canada after 2000, our findings show that this decline can be explained by differences in the labor markets between the two countries (rather than changes in the social safety net). Estimating a pooled difference in difference model controlling for local labor market conditions, the relative changes in labor force participation for single mothers across the two countries is statistically indistinguishable.

Our evidence also suggests that poverty rates, measured both using after tax and transfer income and with private income, have declined with the introduction of the EITC and NCB. By the end of the period, the overall incidence of poverty, however, is lower in Canada compared to the U.S. reflecting the more generous system (and its stronger cash 
welfare system). While the effects of these policy changes on poverty for single mothers are qualitatively similar across the two countries, they also reflect the different policy choices. The U.S. system, built on work requirements, leads to poverty improvements that reflect relatively more gains in market wages while the Canadian system, mainly without work requirements and more universal, leads to poverty improvements more through the benefit system.

The remainder of the paper proceeds as follows. In section II we discuss the social safety nets in the two countries and document the major changes that have taken place over the past 25 years. In Section III we briefly discuss the previous literature examining the effects of EITC and the NCB on employment and poverty. In Section IV we present trends for women with children based on tabulations from the Current Population Survey (for the U.S.) and the Survey of Labour and Income Dynamics (for Canada). In Section V we present estimates from a pooled difference-in-difference model comparing single women with kids to single women without kids in both Canada and the US. By combining data from the two countries and controlling for the differing labor market conditions, we better identify what is driving differences in employment and poverty. We conclude in Section VI.

II. Major changes in social safety net in the U.S. and Canada over the past 25 years Changes in the United States

Over the past twenty-five years, the social safety net for families with children in the U.S. has changed dramatically. The main changes in the cash or near-cash benefits include a reduction in cash welfare (welfare reform), the expansion of the Earned Income Tax Credit and the introduction and expansion of the Child Tax Credit. 
Since 1935, a central feature in the U.S. safety net for families with children was a cash welfare program known as Aid to Families with Dependent Children (AFDC). The program was means-tested, requiring families to satisfy income and asset tests. The benefits were structured in a manner typical for income-support programs: If a family had no income, they received the maximum benefit (guarantee) and as earnings increased the benefit was reduced by the benefit reduction rate. States set the overall generosity of AFDC, by setting the maximum benefits. The benefit reduction rate was high—varying over time between 67 percent and 100 percent--providing strong disincentives for work (Moffitt, 1983). AFDC provided an income floor, though a fairly low one: on the eve of welfare reform the median state maximum benefit was 36 percent of poverty (U.S. House of Representatives, 1996).

Concerns about disincentive to work and form two-parent families led to the reform of the program. This began in the early 1990s, when about half of the states were granted waivers to modify their AFDC programs. Following this, the Personal Responsibility and Work Opportunity Reconciliation Act (PRWORA) was enacted in 1996, eliminating AFDC and replacing it with Temporary Assistance for Needy Families (TANF). The key elements of PRWORA include work requirements, lifetime time limits on the duration of welfare receipt, financial sanctions for failing to adhere to the work requirements or other rules, and enhanced earnings disregards. The time limit (statutorily limited at 5 years but set as low as 2 years by some states) is an important provision in the law in that it eliminated the entitlement nature of the program. The federal funding also changed from an (uncapped) matching formula under AFDC to a (capped nominal) block grant under TANF. Under TANF, states have enormous flexibility in how and on whom the block grant is spent. In 
2014 , on average only 26 percent of the block grant is used for cash benefits with about 10 states spend less than 10 percent of the block grant on cash (compared to nearly $100 \%$ for AFDC). In 2014 only 26 of every 100 families with children in poverty receives cash benefits, down from 72 of every 100 in 1996 (Bitler and Hoynes 2016a).

At the same time that out of work assistance (welfare) was contracting, in work assistance through the Earned Income Tax Credit was expanding. The EITC began in 1975 as a modest program aimed at offsetting the social security payroll tax for low-income families with children. The EITC is refundable so that a taxpayer with no federal tax liability receives a tax refund from the government for the full amount of the credit. Taxpayers receive the EITC as an annual payment as part of their federal taxes. Receipt of the EITC requires earned income and at low levels of earnings the credit is a pure earnings subsidy. At higher levels of income, the credit is phased out. EITC generosity increases with number of children (capped at three or more children) ${ }^{1}$ and a very small credit exists for individuals with no children. In 2017, a family with two children has a phase-in rate (earnings subsidy) of $40 \%$ for earnings up to $\$ 14,040$, beginning at $\$ 18,340$ the credit is phased out at a rate of $21.06 \%$ percent. The maximum benefit is $\$ 5,616$ and at $\$ 45,007$ they earn enough to be ineligible for the credit (Tax Policy Center 2016a). ${ }^{2}$ The EITC is based on joint income; married couples have the same phase-in rate, maximum benefit, and phase-out rate, but the phase-out region begins at a higher earnings level $(\$ 5,550$ higher in

\footnotetext{
${ }^{1}$ Qualifying children must be under age 19 (or 24 if a full-time student) or permanently disabled and residing with the taxpayer for more than half the year.

2 In 2017, the parameters for other groups are as follows, for families with one child (three or more children) the phase-in rate is $34 \%(45 \%)$, the maximum credit is $\$ 3,400(\$ 6,318)$ and the phase-out range is from $\$ 18,340$ to $\$ 39,617$ ( $\$ 18,340$ to $\$ 48,340$ ). For taxpayers without children the subsidy rate is $7.65 \%$, maximum credit is $\$ 510$, and the credit is phased out between $\$ 8,340$ and $\$ 15,010$.
} 
2016).

Significant expansions to the EITC have taken place since 1990. In 1990 the credit was expanded and in 1993 it was expanded more significantly. The 1993 law more than doubled the maximum credit for families with two or more children (from \$1,511 in 1993 to $\$ 3,556$ in 1996$)$ and increased by 50 percent for families with one child $(\$ 1,434$ to $\$ 2,152)$. The 1993 law also introduced a very small credit for taxpayers without children (in 2017, a maximum credit of $\$ 510$ compared to $\$ 3,400$ for those with one child). In 2009 as part of the American Recovery and Reinvestment Act, the separate schedule for families with three or more children was added. The EITC is received by 28 million tax filing units, almost 20 percent of all tax filers and 44 percent of filers with children receive the EITC (Internal Revenue Service 2016). ${ }^{3}$

The Child Tax Credit (CTC) was introduced in 1997. It is structurally similar to the EITC, but more universal in design and less targeted on lower-income families. The maximum credit is $\$ 1,000$ per child less than 17 . The phase in rate is $15 \%$; with a very large flat zone for the credit and a low phase-out rate (5\%), the credit extends to families with incomes as high as $\$ 150,000$ for married couples $(\$ 115,000$ for singles $)$ for families with two children. Unlike the EITC, the CTC is not inflation adjusted; the nominal maximum credit has been unchanged at \$1,000 per child since 2003.

The CTC, unlike the EITC, is not fully refundable. The refundable portion of the CTC is known as the Additional Child Tax Credit (ACTC), and is limited to $15 \%$ of earned income

3 The EITC is federal, but states can and do include EITCs as part of the state income tax system. As of 2016, twenty-six states offer state EITCs (Center for Budget and Policy Priorities 2016), though they tend to be small add-ons to the federal credit, averaging around 15-20\% of the federal credit (Tax Policy Center, 2016b). 
above a fixed threshold. This threshold was $\$ 11,750$ (in nominal dollars) in 2007, preventing most low income families from receiving meaningful CTCs. But in 2009, the American Recovery and Reinvestment Act reduced the threshold to $\$ 3,000$ (again nominal). This allowed more taxpayers to claim the ACTC and increased the amount of refundable credits, making the low-income portion of the schedule more similar to the EITC.

In addition to the cash or near cash safety net, the two more important inkind programs for low income families with children are food stamps and Medicaid. Food stamps, now known as Supplemental Assistance for Needy Families or SNAP, is a meanstested program and benefits are based on maximum benefit level that is reduced with additional earnings using a benefit reduction or phase-out rate. While the eligibility and benefits are like cash welfare, it is a voucher that can be spent on (most) food items in the grocery store. Benefits are adjusted for changes in prices each year. It is federal and has little variation and little scope for rule-setting by states. The benefit reduction rate for SNAP is relatively low for a welfare program (30 percent), the gross income eligibility threshold is higher (at 130 percent of poverty) than other U.S. cash welfare programs, thus the program serves the working and non-working poor. ${ }^{4}$ It has largely remained unreformed during this time period.

While not though the focus of our analysis, another important change during this

\footnotetext{
${ }^{4}$ Welfare reform left Food Stamp rules relatively unaffected. However, beginning with regulatory changes in 1999 and continuing with the 2002 Farm Bill, the USDA has allowed states to make changes in how they implement the program's rules to facilitate obtaining access to benefits. This has led to a relaxation of asset requirements and expanded gross income eligibility in what has been called broad-based categorical eligibility (U.S. Government Accountability Office, 2007).
} 
period is the expansion of public health insurance for low to moderate income children. This began with expansions to Medicaid (between 1986 and 1990), followed by the introduction of and expansions to the State Children's Health Insurance Program (introduced in 1997, expanded in the 2000s), and most recently with the Affordable Care Act of 2010. The result is a dramatic decline in the share of children who are uninsured from 13\% in 1990 to $6 \%$ in 2015 (Child Trends 2016). ${ }^{5}$

\section{Changes in Canada}

The structure of the social safety net for families with children in Canada also changed significantly since the early 1990s. Most significantly, in 1993 Canada introduced the Canada Child Tax Benefit (CCTB), a refundable tax credit (replacing the former child tax credit and family allowance) payable to families with children up to 17 years old. The benefit is paid monthly from July to June based on reported income in the previous tax year. The benefit increased with the number of children. Importantly, there was no work requirement to receive the benefit (thus those with and without earned income received the benefit). As of 2014-2015 the benefit phased out for family net income over $\$ 43,953$ at a rate of $2 \%$ for one child and $4 \%$ for two or more children. In 1998 Canada added the National Child Benefit Supplement (NCB) to the CCTB, aimed, in part, at assisting parents in transitioning from welfare to work. The benefit, based on the number of children, is paid in addition to the CCTB and for net incomes over $\$ 25,584$ (in 2014-15) it phased out more sharply at rates of $12.2 \%$ for one child, $23.0 \%$ for the second child and $33.3 \%$ for the third.

\footnotetext{
5 The period has also seen a steady decline in real value of federal minimum wage. The current rate of $\$ 7.25$ has been fixed in nominal terms since 2009. In the recent period, there have been many cities and states that are setting and expanding local minimum wages above the (low) federal rate. This is not an element of the social safety net per se, but is highly relevant for a social safety net built around work.
} 
The NCB was a joint federal-provincial program and provinces could, at their discretion, subtract NCB payments from their welfare programs and use the recovered funds for other social programs. As a result, the benefits available through the NCB differ significantly across provinces. Overall, the CCTB / NCB benefits phase out at higher earnings and less steeply than cash welfare, leading to increases in the work incentives that single mothers face.

In 2006 the Canadian government added a universal child care benefit of $\$ 100$ per month for each child under age 6. Unlike the CCTB this benefit is taxable and was paid together with the CCTB and NCB. In 2007 Canada also added a Working Income Tax Benefit (WITB), similar in structure to the EITC in that it supplements earned income. It is available to low income earners (regardless of whether they have children or not) and, like the CCTB and NCB, the amount payable has increased over time. It is paid separately (quarterly from other benefits). At the federal level there are a few additional tax credits available to families that are still available (the federal dependent children tax credit and related credits).

Finally, as of July 2016 the government of Canada introduced the new Canada Child Benefit (CCB) to replace the existing child benefit programs (the combined Canada child tax benefit, national child benefit and universal child care benefit). The new CCB is $\$ 6400$ (tax free, unlike the universal child care benefit) for each child up to age 5 and $\$ 5400$ for each child ages $6-17$. The benefit is phased out starting at $\$ 30,000$ with a second kink point at $\$ 65,000$ family net income. The phase out rate depends on the number of children. ${ }^{6}$ The

\footnotetext{
6 The reduction is calculated as follows: families with one eligible child: the reduction is $7 \%$ of the amount of AFNI between $\$ 30,000$ and $\$ 65,000$, plus $3.2 \%$ of the amount of AFNI over $\$ 65,000$. Families with two eligible children: the reduction is $13.5 \%$ of the amount of AFNI between $\$ 30,000$ and $\$ 65,000$, plus $5.7 \%$ of the amount of AFNI over $\$ 65,000$. Families with three eligible children: the reduction is $19 \%$ of the amount of
} 
benefit is paid monthly starting in July of each year. Given how new this change is, we note the new program here but it is not included in our empirical analysis below.

The provinces also offer a variety of supports for low-income families including both welfare programs and cash benefit income programs (for example, Ontario offers the Ontario Child Benefit, similar in design to the National Child Benefit, which we include in our hypothetical budget constraint below). Instead of describing these programs in detail here we list the major provincial benefit programs in Appendix A. In general, programs have evolved in a number of provinces alongside the federal benefits, toward families with children and away from single individuals, although (smaller) welfare programs do remain.

Overall, Canada's social safety net has evolved over the past two decades toward providing more resources for families with children. In some cases these have replaced some of the support that was previously available through social assistance/welfare programs for families in the provinces. Traditional welfare benefits, on the other hand, remain the primary source of support for individuals without children. Notably, the new family benefits do not require labor market income to qualify (with the exception of the WITB which makes up a fairly small portion of the overall support). Finally, the programs work to reduce the welfare wall that exists in most social security programs with a gradual phase out of benefits with earned income of approximately $\$ 15,000$, particularly in those provinces that integrated increased family benefits with declining welfare benefits. Comparing the sources of support in Canada and the United States.

To summarize these programs, Figure 1 plots real per capita expenditures since

AFNI between $\$ 30,000$ and $\$ 65,000$, plus $8 \%$ of the amount of AFNI over $\$ 65,000$. Families with four or more eligible children: the reduction is $23 \%$ of the amount of AFNI between $\$ 30,000$ and $\$ 65,000$, plus $9.5 \%$ of the amount of AFNI over $\$ 65,000$. 
1990 for AFDC/TANF, EITC, the CTC, and SNAP. Post welfare reform, cash welfare (TANF) has declined dramatically. The EITC, on the other hand, has increased substantially. The CTC has expanded recently and spending has almost reached the levels of the EITC and SNAP.

While we are unable to report per capita expenditure by program in Canada, we report aggregate per capita spending (including federal, provincial and local government spending) over time in Canada in figure 1b. While there was an initial decline in per capita social spending through the mid-1990s (Canada went through a major deficit reduction exercise during this period beginning in 1995) it was followed by an increase in spending to almost pre-1994 levels over the 2000s, in part generated by the introduction of new federal programs and increased generosity of the NCB over this period.

Figures 2 and 3 show the cash and near cash sources of support for hypothetical families in the U.S. and Canada. For each country we consider a single mother with two children and simulate the benefits for a range of annual earnings; all benefits amounts and earnings are in 2015 (Canadian or U.S) dollars. ${ }^{7}$ These figures show only positive elements of the tax and transfer system (i.e. do not include income taxes paid).

Beginning with the U.S., we present the budget constraint for 1992 (Figure 2a) and 2015 (Figure 2b) for a single mother with two children living in Colorado. In 1992, welfare is still an entitlement, the EITC has not been expanded, and the CTC has yet to be introduced. Comparing the budget constraints in 1992 and 2015, we see striking evidence of the shift in resources away from out of work to in-work. For example, in 1992 a single

\footnotetext{
${ }^{7}$ For the U.S. calculations, we assume that the household spends $\$ 6,000$ per year on child care, $\$ 8,400$ per year on housing, and that the children are ages 4 and 6 . For Canada we assume 2 children under the age of 18 living in Ontario.
} 
mother with two children who is not working receives $\$ 12,600$ (2015 USD) in assistance (AFDC+SNAP), this falls by half to $\$ 6,132$ (2015 USD) in 2015. In 2015 if the woman works full time at the federal minimum wage (of $\$ 7.25$ ) she would earn about $\$ 15,000$. Benefits for this minimum wage full time worker rises from about $\$ 5,206$ in 1992 to $\$ 11,600$ (both in 2015 USD). This is a striking change. Also clear in these budget constraints are the high implied tax rates faced by very low earning women in 1992 in contrast to the negative tax rates for the same women in 2015.

The Canadian budget constraints illustrate the programs available for a single parent family with two children in the province of Ontario. In 1992 (Figure 3a) the major source of support was welfare provided through the provinces. Federal supports came through a series of small tax credits. By 2015 (Figure 3b) welfare (labeled "Ontario Works") plays a much smaller role in the total support available, focused mainly on those with very low incomes. Instead, the Canada Child Tax Benefit (taking the place of the largest of the 1992 credits), National Child Benefit, Working Income Tax Benefit, and Universal Child Care Benefit provide considerable support for a much larger share of the population. The structure of benefits changes significantly over this period. Ontario works, like most cash welfare programs, provides out of work benefits that are phased out sharply even at the lowest earnings levels. In contrast, the CCTB and NCB phases out more slowly and the phase out begins at much higher earnings levels (more than $\$ 20,000$ ). In contrast to the EITC, the CCTB and NCB are also available to those out of work. The WITB phases in with earned income, like the EITC, and the UCCB is universal. A child benefit in Ontario supplements the federal child benefits, operating in much the same fashion as the NCB.

Overall, several features stand out in these figures. First, there have been significant 
changes in policy design in both countries over the past few decades. The nature of support, the conditions required, and the generosity have all changed in both countries.

Second, for families with children, both countries have moved away from a welfarebased out-of-work benefit system with high phase-out rates that dominated both countries in 1992. Figure 2a and 3a show that in 1992, welfare was the main source of support in Canada (e.g. Ontario Works) and the U.S. (e.g. AFDC plus SNAP). Benefit levels were higher in Canada, but both countries targeted the non-working poor and high phase-out rates would be expected to discourage work. Both countries have introduced programs that move away from pure out of work assistance. In the US, the EITC provides strong incentives to enter work (and cash welfare was substantially reduced) and Canada implemented an EITC-like in work credit (Working Income Tax Benefit) thereby lessening the work disincentives of a welfare based support system. ${ }^{8}$

Third, benefits in Canada start with universal (or near universal) child supports that are not tied to work. This includes the universal child care benefit, the national child benefit supplement, the child tax benefit as well as the provincial versions of these programs. However, in contrast to cash welfare, the child supports have lower phase-out rates that begin at higher earnings levels. The combined effect is to encourage work relative to before these programs were implemented. In contrast, the U.S. is almost entirely based on a system of benefits tied to work; the EITC and the child related tax credits all require wage income in order to qualify and over the range that affects the poorest families, benefits increase as wage income increases. The incentives to work embedded in the EITC are

8 The working income tax benefit, while similar to the EITC in design, makes up a much smaller share of the total benefit available to families. 
therefore stronger than those in Canada. Post-welfare reform. SNAP is only source of out of work assistance, and thus while in work benefits have expanded the basic income floor has decreased. We consider the difference in work requirement across the two countries one difference that may matter.

Fourth, the level of generosity between the two sets of programs is quite different. In both 1992 and 2015 Canada provides more support to low income families. For example, in 1992, the maximum benefit in the U.S. (e.g. that received if not working), including cash and near cash benefits such as food stamps (Figure 2a) was approximately $\$ 13,000$ (2015 USD). This fell to a little over $\$ 6,000$ (2015 USD) in 2015 (Figure $2 \mathrm{~b}$ ) primarily due to the reform of cash welfare. The maximum cash benefit in Canada in 1992 is about $\$ 27,000$ (2015 CDN) and fell to about $\$ 25,000$ (2015 CDC) in 2015. (PPP across the two countries over much of this period is approximately 1.22 although the exchange rate fluctuated considerably ${ }^{9}$ ). At an earnings level of $\$ 20,000$ in 2015 , benefits are about $\$ 20,000$ in Canada compared to $\$ 12,000$ in the US. Thus, clearly Canada provides a much higher level of support, particularly so for those at very low or zero earnings. The difference in the generosity of the social safety net is a second difference that may matter.

We include similar budget constraints for childless adults for both countries in Appendix Figures 1 and 2. What is immediately evident is that the range of benefits available for single individuals is considerably more limited in both countries. In Canada the available benefits are welfare benefits and the small working income tax benefit. In the U.S. benefits for childless individuals are SNAP and a small EITC. The Canadian out of work benefits are more generous - the maximum benefit for a single person is $\$ 7,872$ in 2015 in

${ }^{9}$ World Bank (2017) 
Ontario, Canada (the benefits are at the provincial level)_ compared to $\$ 2,000$ in the U.S. In order to understand how these changes in benefits coupled with income taxes have affected the incentives to work in the two countries we calculate the average tax rate (ATR) imposed by moving from (1) no work to part-time work, (2) no work to full-time work, and (3) part-time work to full-time work. The ATR are calculated based on all of the benefits modeled in the budget constraints above as well as ordinary income taxes. We calculate average tax rates for single women with two children (as in the budget sets above). We use the nominal minimum wage in each country in $2015^{10}$ and the real value of that wage in 1992 as a representative wage, along with $125 \%, 150 \%$ and $200 \%$ of the minimum wage, and consider part time work as 20 hours per week and full time work as 40 hours per week. The results are reported in Table 1. The top panel presents the average tax rates for the U.S. in both 1992 and 2015. The difference in the U.S. average tax rates between 1992 and 2015 is striking. Whereas tax rates were almost always above 50\% for individuals moving from no work to work and part time to full time work in 1992, by 2015 they were negative for moving to part-time work in all four wage categories and remain significantly smaller for movements into full time work. For example, a single mother with two children working at $150 \%$ of the minimum wage faces a $-9 \%$ average tax rate for entering full time work in 2015 compared to 53\% in 1992. For moving from part to full time work the average tax rate has fallen from $45 \%$ to $26 \%$. Overall the incentives to work in the U.S. have risen dramatically over this period for single mothers in the U.S.

The average tax rates also declined across all wage and work levels in Canada (bottom panel of Table 1). For example, a single mother with two children working at

10 This amounts to \$7.25 USD in the U.S. and \$11 CAD in Canada. 
$150 \%$ of the minimum wage faces a $52 \%$ average tax rate for entering full time work in 2015 compared to $83 \%$ in 1992 . For moving from part to full time work the average tax rate has fallen from $106 \%$ to $70 \%$. This is a significant decline in average tax rates in Canada which given the cumulative phase out of welfare and provincial benefits, could exceed $100 \%$ in 1992 . However, compared to the U.S. the average tax rates remain high average tax rates from moving between not working to part or full time work range from a low of $24 \%$ to as high as $75 \%{ }^{11}$. The differences between Canada and the United States reflects the fact that, with the exception of the WITB, most of the benefits in Canada are at their maximum at zero income, and while the phase out of the child benefits does not occur with the first dollar of earnings, an individual working full time at minimum wage is well into the phase out range. Appendix Table 1 shows the ATRs for single women without children; it is evident that work disincentives for this group have not changed much over time and remain quite high (in an absolute sense, and compared to single women without children).

Our budget set and tax rate analysis suggests several predictions for the trends in employment and poverty across the two countries. The changes in the social safety net should lead to increases in employment for single women with children, relative to single women without children, in both the U.S. and Canada. All else equal, employment should rise by more in the U.S. than in Canada given the greater decline in average tax rate. Poverty should decline in both countries, though the U.S. decline should reflect more heavily gains in market income (due to the work requirement) while the Canadian decline

\footnotetext{
11 By 2015 Ontario had ended the clawback of welfare benefits from the NCB. Ignoring changes in income tax rates, the change in average tax rates would have been even larger over some ranges had the clawback remained in place.
} 
should reflect more heavily gains in benefits (due to the universality of benefits). All else equal, we would also expect that absolute level of poverty rates would be higher in the U.S. compared to Canada, given the higher level of support in Canada (throughout the period). Additionally, we expect deep poverty (those with income less than $50 \%$ of the poverty line) to have risen in the U.S. relative to Canada given the reduction in out-of-work support postwelfare reform..$^{12}$

III. Previous literature

There is a substantial amount of evidence about the effects of the U.S. EITC and Canadian NCB on family and child wellbeing over the past two decades and we discuss only some highlights of it here. For more comprehensive reviews of the effects of the changes in the social safety net, see the studies on welfare reform (e.g., Blank 2001, 2002, Grogger and Karoly 2005, Moffitt 2003, and Ziliak 2016) and the EITC (Hotz and Scholz, 2003, Nichols and Rothstein 2016, Hoynes and Rothstein 2016, Eissa and Hoynes 2006). In particular, studies show that the EITC leads to substantial increases in employment for single mothers (e.g., Eissa and Liebman 1996, Meyer and Rosenbaum 2000, 2001, Hoynes and Patel 2015) with little evidence that existing workers reduce hours worked. ${ }^{13}$ Many of these studies use a difference-in-difference approach comparing single women with children to women without children (who are eligible only for a very small EITC) in periods before and after an

\footnotetext{
${ }^{12}$ A final difference that isn't evident in the figures but that potentially affects the effectiveness of the social safety net is how benefits are paid to recipients. In Canada, the CCTB/NCB/UCCB are all paid monthly. The WITB is paid quarterly. In the U.S., the EITC and the CTC is paid annually. (Food stamps are paid monthly.) ${ }^{13}$ Some studies show that self-employed workers adjust to maximize the credit along the phase-in region (Chetty, Friedman and Saez 2013, Saez 2010, Chetty and Saez 2013).
} 
expansion in the EITC. The magnitudes are large - for example, Meyer and Rosenbaum (2001) find that the EITC raised labor force participation by 7.2 percentage points for single women with children relative to those without children between 1984 and 1996. Hoynes and Patel (2015) find that the 1993 expansion increased employment of single mothers with less than a college degree by 6.1 percentage points. ${ }^{14}$

Milligan and Stabile (2007) investigate the effect of the introduction of the Canadian NCB, and the ability of provinces to choose to subtract NCB payments from social assistance/welfare, on the labor force participation of single mothers. The findings suggest substantial labor market effects from the integration of benefits and social assistance. A $\$ 1000$ increase in benefits deducted from social assistance payments is associated with a 34 percentage point decline in social assistance take up and an equivalent 3-4 percentage point increase in employment. The effects are concentrated on the extensive margin of labor force participation.

A handful of studies have estimated the effect of the EITC on poverty. Hoynes and Patel (2015) use a difference-in-difference approach and find that the 1993 EITC expansion led to a 7.9 percentage point reduction in poverty. Their finding suggest that ignoring the indirect effects of the EITC (increased earnings net of changes in other income) leads to an underestimate-by as much as a 50\% --of the anti-poverty effects of the EITC. Earlier studies examined the effect of state EITC supplements on poverty (Neumark and Wascher 2001, Gunderson and Ziliak 2004) finding qualitatively similar effects.

\footnotetext{
14 Eissa and Liebman (1996) examined the earlier 1986 expansion of the EITC and find that labor force participation increased by 2.8 percentage points for single women with children, relative to single women without children.
} 


\section{Trends in demographics, employment and poverty}

In this section we examine the trends across the U.S. and Canada in demographics, female employment and absolute poverty. Our analysis uses data from the U.S. Current Population Survey (CPS) and the Canadian Survey of Labour and Income Dynamics where we have harmonized the sample, data and variables to maximize comparability across the two countries. To focus on the working age population, for both countries we limit our analysis to women aged 25-54. Because of our interest in the social safety net and the disadvantaged, our core sample is single women who have less than a college degree. ${ }^{15}$ To highlight the trends for single mothers, we compare trends across two groups: single women with children and single women without children. We use a time period that spans the major changes in the social safety net that we describe above though the exact years differ somewhat across the two surveys. We briefly describe the two surveys below; for more details on our data and variable construction, see the Appendix B.

For the U.S. analysis, we use the Annual Social and Economic Supplement to the Current Population Survey, administered to most households in March every year. The CPS-ASEC is an annual survey of about 90,000 households (or about 175,000 persons) that collects labor market, income, and program participation information for individuals for the previous calendar year, as well as demographic information at the time of the survey. Our sample uses the 1991 through 2012 CPS-ASEC surveys, corresponding to the 19902011 calendar years. Employment is measured as having any work during the calendar year. We measure income and poverty at the household level, after dropping unrelated

\footnotetext{
15 This includes those with less than a high school degree, those with a high school degree or GED, and those who have some college but less than a four year degree.
} 
children (as does the Census Bureau). Our analysis is weighted using the March supplement person weight.

For the Canadian analysis, we use the Survey of Labour and Income Dynamics (SLID). The SLID is conducted annually by Statistics Canada with a stratified random sampling of Canadians. As with the CPS, with survey weights, the data are nationally representative. Our analysis uses public-use cross sectional individual and census family files providing data for calendar years 1996 through 2011. ${ }^{16}$ The SLID provides information on income and benefits received over the past year and detailed information on demographics at the time of the interview. The survey consists of approximately 55,000 people per year, our sample of women ages 25-54 results in a sample of approximately 16,000 per year (considerably smaller than the corresponding sample in the CPS). For the purpose of the Canadian analysis we treat individuals as married if they report being either married or common law married and single otherwise.

\section{Trends in demographics}

We begin by examining trends in the demographics underlying our sample of single women with children. Figure 4 presents the share of women 25-54 with less than a college education who are single with children, in the U.S. and Canadian samples. Both countries experienced increases in single parenthood, though the rate is much higher in the U.S. The share that are single mothers in the U.S. rose from 17 percent in 1990 to 23 percent by the

16 The SLID replaced the Survey of Consumer Finances (SCF) as the major cross sectional survey for labor market data as of 1996. Using previous years of the SCF or the longitudinal SLID files that exist for the SLID in 1993 and 1994 produced inconsistent samples due to questionnaire changes and collection and weighting changes that made results from previous years misleading. Therefore we begin the Canadian data series in 1996. 
end of the period for those with less than a college degree. The share that are single mothers in Canada (among those with less than a college degree) rose from just over 11 percent in 1996 to 13 percent by the end of the period.

\section{Trends in Employment}

In Figure 5, we plot the share of women 25-54 with less than a college degree who worked at all during the calendar year. For each country we show the share working for single women with and without children; the figure pools this for both countries. While our focus is on single women with children, we include women without children to highlight the changes occurring for single mothers.

In the U.S., employment for non-college graduate single mothers increased sharply between the early 1990s and late 1990s. For example, the share working at all last year increased from 69 percent in 1992 to 82 percent in 2000. This increase closes the substantial gap in employment rates between single mothers and single women without children that existed in the beginning of the period. Beginning in 2000, both groups experience a steady downward trend in employment rates dropping by 10 percentage points over this period.

While the Canadian data start a few years later, we see a striking rise in the employment rate of single mothers - rising from 62 percent in 1996 to 77 percent in 2001. As with the U.S., this rise in employment closed the substantial employment gap (between single women with and without children) that existed in the beginning of the period. In contrast to the U.S., both groups experience steady employment through the end of the period (2011) where the employment rates hover between 75 and 80\%. Figure 6 presents similar trends for full time work. Overall, these figures show similar patterns to those for 
any work in Figure 5. Notable, though, among single mothers with less than a college degree, full-time employment rates are higher in Canada - ranging from 60 to 67 percent compared to the peak in 2000 in the U.S. at 62 percent.

Importantly, the post-2000 trends in Figures 5 and 6 differ significantly between the U.S. and Canada. In the U.S., growth declined significantly after the historically strong labor market of the late 1990s. This was punctuated by the Great Recession and the significant downturn between 2008 and 2010. To illustrate the dramatic differences that emerge in the macroeconomy over this period, Figure 7 presents the annual unemployment rate series for both countries from 1990-2015. Historically, the U.S. unemployment rate has been lower than Canada's and the countries follow similar fluctuations. However, the U.S. experienced a steady increase in unemployment in the 2000s along with a sharp increase in the Great Recession. In contrast, while Canada's unemployment rate was higher over the 1990s and early 2000s, Canada experienced a much smaller recession in 2008 followed by a quicker recovery. This makes it quite difficult to derive conclusions about the role of the social safety net by comparing trends across countries. We take a deeper dive into those issues in the next section.

Trends in poverty

To broaden our analysis to examine family well-being, here we examine trends in poverty across the two countries. To facilitate comparisons across countries, we adopt the OECD definition of absolute poverty (Organisation for Economic Cooperation and Development, 2015), also recently highlighted in a UNICEF series on child poverty in the Great Recession (UNICEF 2014, Bitler, Hoynes and Kuka 2014). The main advantage of this approach is that one does not have to grapple with a different absolute poverty threshold 
across the two countries. ${ }^{17}$

We construct the poverty rates for each country using the following process. First, we compute an after tax and transfer (ATT) income measure for the family or household. ${ }^{18}$ Second, we compute equivalized ATT income (i.e. ATT income / equivalized household size; where equivalized household size is computed using the OECD modified scale ${ }^{19}$ ). Third, we compute the median of the equivalized ATT income in our base year, 1996 (chosen because it is the first year in the SLID; we use the same for the U.S.). The absolute poverty line for 1996 is then $60 \%$ of the median of equivalized ATT income for 1996 (in each country). To compute the absolute poverty lines for the other years, we start from the 1996 poverty line just computed and adjust for inflation. We refer to these as the "country

17 Official poverty in the U.S. is determined by comparing total pre-tax family cash income to poverty thresholds, which vary by family size, number of children, and presence of elderly persons. The poverty thresholds reflect a basket of goods set in the 1960s and are adjusted each year for changes in prices. For example, in 2015, the poverty threshold for a family of three (one adult, two children) was $\$ 19,096$. This measure has many drawbacks, in particular is its omission of the key sources of support that we examine here: SNAP (because it is inkind not cash), and the EITC and CTC (because they are taxes). The Census now releases the Supplemental Poverty Measure along with official poverty in its annual poverty reporting (Short, 2011). The SPM resource measure expands to include the cash value of various in-kind transfers and nets out taxes (and deducts from income child support payments, medical out of pocket expenditures, and work expenses including child care). Additionally, the SPM family unit is modified to include cohabitors and their children and poverty thresholds vary geographically. The Census SPM thresholds are defined to be the average between the 30th and 36th percentiles of the distribution of consumer expenditures on food, clothing, shelter, and utilities plus an additional 20 percent to account for additional necessary expenditures. This makes the SPM a "quasi-relative" poverty measure.

18 In the U.S. we use a "household" sharing rule, combining the income of all persons living in the same household (excluding unrelated children). This allows for clear measurement of inkind sources of income, including SNAP and energy assistance. See Bitler and Hoynes (2016b) and Bitler, Hoynes and Kuka (2016) for more information on this measurement. In the Canada we use the Census family (those related by birth and marriage). In practice in the differences in outcomes for the Census and household income and poverty are minimal. 19 The OECD equivalized scale equals 1 for the head plus 0.5 for each additional adult [age $14+$ ] plus 0.3 for each child [age < 14]. 
specific" absolute poverty rates.

In addition to computing poverty rates using country-specific poverty thresholds, we also compute a pooled poverty threshold using a modification of the methodology described above. First, we convert Canadian income in each year to U.S. dollars using published OECD PPP values for that year and then calculating the 1996 absolute poverty threshold as described above, but using the combined U.S.-Canada income distribution (now all in U.S. dollars). The absolute poverty threshold is then adjusted each year using the U.S. CPI. We refer to this as the pooled absolute poverty rate.

If the household (for the U.S.) or Census family (for Canada) has ATT equivalized income below the equivalized poverty line, then they are assigned to be poor. In the case of the combined US-Canada poverty threshold, we compare U.S. ATT income and Canadian PPP adjusted ATT income to the combined threshold. To highlight the role of the labor market versus the social safety net, we also construct a "private income" poverty measure. Here the poverty thresholds remain the same. All that differs is the equivalized income measure that is compared to the threshold. Private income is pre-tax and transfer income and includes earned and unearned income. After tax and transfer income equals private income plus cash transfers and the value of non-cash transfer payments, less payroll taxes and net federal and state/provincial income taxes (including in-work benefits and child tax benefits). For more information on income definitions for both countries see Appendix B.

Figure 8 shows the trends in absolute ATT poverty for women aged 25-54 with less than a college degree using the country-specific poverty thresholds described above. Several things are evident in this figure. In the U.S. poverty rates for single mothers fall between 1993 and 2000 absolutely and relative to single women without children, though 
throughout the period the poverty rate for single mothers remains higher than for single women without children. Following the pattern for employment, beginning in 2000 poverty rates for both groups trend slowly up. In Canada, poverty rates for single mothers throughout most of the period, falling dramatically relative to single women without children. By the end of the period, the poverty rate for single mothers is below that for single women without children (25\% versus $33 \%)$.

To explore the role of the social safety net in these trends, in Figure 9 we compare private income poverty for the two groups of single women with less than a college degree in the two countries. For the U.S. poverty rates for single mothers based on private income are only slightly higher than ATT poverty at the beginning of the period (53\% for private income poverty versus $49 \%$ for ATT poverty), both decline over the 1990 s along with a slightly more pronounced increase over the 2000s for private income than for ATT income, particularly following the Great Recession. In Canada, there is a similar level effect with rates for single mothers starting at $60 \%$ for private income poverty versus $51 \%$ for ATT poverty, with a similar decline over the 1990s and 2000s. However, in Canada private income poverty for single mothers remains higher than for single women without kids over the entire period, whereas ATT poverty levels for single mothers fall below those for women without kids as noted above. In both countries it would appear that while part of the decline in poverty is due to changes in market income, a growing part of the decline in poverty over the 2000s is due to the effects of taxes and transfers. This is particularly so for Canada.

Figures 10 and 11 present trends in both ATT and private income poverty using a pooled poverty measure across the two countries calculated using the combined income 
distribution (as described above). Perhaps surprisingly, using the pooled poverty threshold reveals very similar patterns despite differences in income distribution between the two countries. In the U.S. the drop in poverty rates for single mothers over the 1990s remains as does the uptick over the 2000s. For Canada, poverty rates for single mothers drop significantly over the 1990s and then continue to drop over the 2000s, passing the U.S. poverty rate in 2005 and the rate for single women without children in Canada in 2006. Similarly, using private income the decline in both countries is smaller and the poverty rate for single mothers in Canada crosses that of the U.S. in 2007 and remains always above that for single women without children.

Summary and connection to policy changes

The trends in employment and poverty match the predictions of the policy changes, discussed above. Single mothers in the U.S. and Canada increased employment closing the historical employment gap between single women with and without children. Single mothers also experienced reductions in poverty during this period, absolutely and relative to single women without children. Consistent with the different models for reform, the U.S. decline in poverty may be more driven by changes in market income while the Canadian decline is more driven by changes in benefits. This reflect the work requirement in the U.S. policies and a more universal approach in Canada. Additionally, by the end of the period, absolute poverty rates in Canada are lower, consistent with the greater generosity in the Canadian programs. On the other hand, given the work requirements in the U.S. and the greater reductions in average tax rates embodied in the U.S. reforms (Table 1), we predicted a larger increase in employment in the U.S.; the data is not consistent with that prediction. One possible confounder is the difference in the macro labor market conditions 
across the two countries. We turn to that next.

V. Relative Trends in Employment and Poverty Combining U.S. and Canadian Data

In order to better understand how much the different underlying labor markets between the two countries drive the effects of the social safety net on single mothers we use a regression framework where we combine the micro data from the two countries to estimate models of employment and poverty rates. We combine the 1990 through 2011 data from the CPS and the 1996 through 2011 data from the SLID. Our sample consists of all unmarried women ages 25 to 54 with less than college education in both countries. We estimate a pooled difference-in-difference model while controlling for local labor market conditions. In particular, the model includes fixed effects for the year*country, year*country*single mother, state/ province as well as controls for the unemployment rate (at the state/province x year level) and an interaction between the unemployment rate and being a single mother ${ }^{20}$. We then plot the interaction terms for Canada * year * single mother and US * year * single mother, using 1996 as a base year for both countries. This allows us to examine the employment and poverty trends for single mothers relative to single women without kids relative to the base year of 1996 for the two countries. We present these results in figures 12 through 14.

Figure 12 shows the relative trends for employment. Relative to 1996 and

\footnotetext{
${ }^{20}$ As specification checks we run these models a) excluding Quebec from the analysis as Quebec launched a subsidized day care program in 1997 that may have had separate effects on employment for single mothers and $b$ ) include a dummy variable for those province/years in Canada where welfare payments were reduced by the amount of the NCB payment for NCB recipients. Ontario, Alberta, Manitoba, Nova Scotia and Prince Edward Island all began by clawing back welfare payments from NCB recipients at the start of the program.
} 
controlling for time trends and overall unemployment rates, employment for single mothers (relative to single women without children) improved in both countries. While the raw employment rates for single mothers presented in Figure 5 looked quite different for the U.S. and Canada, once we normalize relative to the single women without children in the country and control for difference in labor markets, the trends are remarkably similar. ${ }^{21}$ The results are unchanged if we remove Quebec from the analysis and control for the Canadian claw-back provinces.

Figures 13 and 14 present similar results for absolute poverty levels using after tax and transfer (ATT) income as well as using just private income. For these comparisons we use the pooled poverty measure across the two countries described in section IV above. Absolute poverty rates for single mothers using ATT income fell in both countries relative to 1996 and single women without children. Once again, the relative decline in the two countries, once we control for labor market differences, appears to be quite similar with no statistically significant differences between the two trends. On the other hand, looking at private income (Figure 14) the relative decline in the U.S. over parts of the sample range is slightly larger, although no different post the Great Recession ${ }^{22}$. This is again consistent with a larger share of the effect of the U.S. social safety net for single mothers coming through market income relative to transfer income.

${ }^{21}$ For employment (figure 12), the changes relative to 1996 and relative to single women without children are not statistically different between the two countries (see p-value for joint test of equality across countries at the bottom of the figure). For poverty, as is clear visually, we can't reject joint equality.

22 The results remain unchanged when we exclude Quebec and control for clawback provinces. 


\section{$\underline{\text { VI. Conclusion }}$}

The introduction of the EITC in the U.S. and the NCB/CCTB (and its successor) in Canada represent a major change in the structure of the social safety net for single mothers in both countries. The programs are striking in both their similarities and their differences. They both reflect a move away from relying primarily on traditional welfare benefits. They both encourage labor force participation either through having work requirements (EITC) or lessening the welfare cliff with the introduction of child benefits that phase out at higher levels (NCB) -- although clearly work incentives are stronger in the U.S. programs. The evidence presented here suggests that these reforms have had positive employment effects on single mothers - the group most targeted by the programs. We find that both sets of programs are associated with a reduction in poverty rates among single women with children. However, it appears that market income plays a larger role in the U.S. - consistent with the stronger employment incentives inherent in the EITC - while benefit income may play a relatively larger role in Canada.

Despite the similarities in outcomes, there are some significant differences between the programs. Perhaps the largest of these differences is in the work requirements: the EITC requires household to work while the NCB/CCTB does not. In theory, we expect this difference to result in greater labor force attachment in the U.S. compared to Canada. Our evidence does not reveal strong differences along these lines as single mothers in both countries experienced labor market improvements. While employment for single mothers without a college degree fell in the U.S. in recent years relative to Canada, the decline (relative to single women without children) is due to the other differences in the labor markets across the two countries. 
Additionally, the generosity of the Canadian social safety net exceeds that of the U.S. This is revealed in lower absolute poverty rates in Canada, particularly in the recent period. However, once the weaker labor market in the U.S. beginning around 2000 is accounted for, poverty declines across the two countries (relative to single women without children) are quite similar. Finally, the lack of an out-of-work safety net in the U.S. suggests we would expect higher rates of deep poverty compared to Canada. We find that more of the decline in poverty in the U.S. is due to market income than in Canada which suggests that those without market income are relatively better off in Canada. More could be done to understand the broader impacts of the social safety net on the distribution of income and inequality in the two countries. 


\section{$\underline{\text { References }}$}

Bitler, Marianne, and Hilary Hoynes. 2010. "The State of the Safety Net in the Post-Welfare Reform Era." Brookings Papers on Economic Activity, 71-127. Brookings Institution, Washington, DC.

Bitler, Marianne, and Hilary Hoynes. 2015. "Heterogeneity in the Impact of Economic Cycles and the Great Recession: Effects Within and Across the Income Distribution." American Economic Review: Papers and Proceedings 105 (5): 154-60.

Bitler, Marianne, and Hilary Hoynes. 2016a. "Strengthening Temporary Assistance for Needy Families," The Hamilton Project.

Bitler, Marianne, and Hilary Hoynes. 2016b. "The More Things Change, the More They Stay the Same? The Safety Net, and Poverty in the Great Recession." Journal of Labor Economics 34 (S1): S403-S444.

Bitler, Marianne, Hilary Hoynes, and Elira Kuka. 2017. "The Great Recession and Child Poverty." Journal of Policy Analysis and Management, Vol. 36, No. 2, 358-389 (2017)

Bitler, Marianne, Hilary Hoynes, and Elira Kuka. 2014. "Child Poverty and the Great Recession in the United States," UNICEF Framing Paper, Innocenti Working Paper No.201411, UNICEF Office of Research, Florence.

Blank, Rebecca. 2002. "Evaluating Welfare Reform in the United States." Journal of Economic Literature 40 (4): 1105-66.

Blank, Rebecca 2001. "Declining Caseloads/Increased Work: What Can We Conclude About the Effects of Welfare Reform?" Economic Policy Review. Vol 7(2):25-36..

Center for Budget and Policy Priorities. 2016. "Policy Basics: State Earned Income Tax Credits," accessed 9/16/16 at http://www.cbpp.org/research/state-budget-andtax/policy-basics-state-earned-income-tax-credits.

Chetty, Raj, John N. Friedman, and Emmanuel Saez. 2013. "Using Differences in Knowledge Across Neighborhoods to Uncover the Impacts of the EITC on Earnings." American Economic Review 103 (7): 2683-721.

Chetty, Raj, and Emmanuel Saez. 2013. "Teaching the Tax Code: Earnings Responses to an Experiment with EITC Recipients." American Economic Journal: Applied Economics 5 (1): 1-31.

Child Trends. 2016. "Data bank: Health Care Coverage", accessed 9/16/16 at http://www.childtrends.org/wp-content/uploads/2016/05/26 Health Care Coverage.pdf.

Eissa, Nada, and Hilary Hoynes. 2006. "Behavioral Responses to Taxes: Lessons from the EITC and Labor Supply." In Tax Policy and the Economy, vol. 20, edited by J. M. Poterba, 74110. Cambridge, Mass.: MIT Press.

Eissa, Nada, and Jeffrey B. Liebman. 1996. "Labor Supply Response to the Earned Income Tax Credit." The Quarterly Journal of Economics 11(2): 605-37.

Grogger, Jeffrey, and Lynn Karoly. 2005. Welfare Reform: Effects of a Decade of Change. Cambridge, MA: Harvard University Press. 
Gundersen, Craig, and James P. Ziliak. 2004. "Poverty and Macroeconomic Performance Across Space, Race, and Family Structure," Demography 41(1): 61-86.

Hotz, V. Joseph, and John Karl Scholz. 2003. “The Earned Income Tax Credit.” In Meanstested transfer programs in the United States, edited by Robert A. Moffitt, 141-197. Chicago: University of Chicago Press.

Hoynes, Hilary W., and Ankur Patel. 2015. "Effective Policy for Reducing Inequality? The Earned Income Tax Credit and the Distribution of Income.” Unpublished Working Paper, July.

Hoynes, Hilary, and Jesse Rothstein. 2016. "Tax Policy Toward Low Income Families."

Meyer, Bruce D., and Dan T. Rosenbaum. 2001. "Welfare, the Earned Income Tax Credit, and the Labor Supply of Single Mothers." Quarterly Journal of Economics 116 (3): 1063-1114.

Meyer, Bruce D., and Dan T. Rosenbaum. 2000. Making Single Mothers Work: Recent Tax and Welfare Policy and Its Effects, National Tax Journal, 53:4: 1027-62.

Milligan, Kevin and Mark Stabile. 2011. “Do Child Tax Benefits Affect the Wellbeing of Children?" American Economic Journal: Economic Policy, 3(3):175-205.

Milligan, Kevin and Mark Stabile. 2007. "The Integration of Child Tax Credits and Welfare: Evidence from the Canadian National Child Benefit Program," Journal of Public Economics, 91(1-2): 305-326.

Moffitt, Robert. 2003. "The Temporary Assistance for Needy Families Program." In MeansTested Transfer Programs, edited by Robert Moffitt. Chicago: University of Chicago Press.

Moffitt, Robert. 1983. An economic model of welfare stigma. American Economic Review 73(5): 1023-35.

Neumark, David and William Wascher. 2001. "Using The EITC to Help Poor Families: New Evidence and a Comparison with the Minimum Wage," National Tax Journal, National Tax Association, 54(2): 281-318.

Nichols, Austin, and Jesse Rothstein. 2016. "The Earned Income Tax Credit." In Economics of Means-Tested Transfer Programs in the United States, Volume I, edited by Robert Moffitt. Chicago: University of Chicago Press.

Organisation for Economic Cooperation and Development. 2015. In It Together: Why Less Inequality Benefits All. Paris: OECD Publishing.

Saez, Emmanuel, 2010. “Do Taxpayers Bunch at Kink Points?” American Economic Journal: Economic Policy 2 (3): 180-212.

Short, Kathleen. 2011. The Research Supplemental Poverty Measure: 2010. Current Population Reports P60-241. Washington. DC: U.S. Census Bureau.

Steuerle, Eugene, and Caleb Quakenbush. 2015. Marginal Tax Rates and 21st Century Welfare Reform. Washington, D.C.: Urban Institute.

Tax Policy Center. 2016a. “EITC Parameters," Accessed on 9/16/16 at http://www.taxpolicycenter.org/statistics/eitc-parameters. 
Tax Policy Center. 2016b. "State EITC Based on the Federal EITC," Accessed on 9/16/16 at http://www.taxpolicycenter.org/statistics/state-eitc-based-federal-eitc.

Tweddle, Anne, Ken Battle, and Sherri Torjman. 2014. "Welfare in Canada, 2013," Caledon Institute of Social Policy, accessed 4/21/2017 at http://www.caledoninst.org/Publications/PDF/1057ENG.pdf.

Tweddle, Anne, Ken Battle, and Sherri Torjman. 2015. "Welfare in Canada, 2014," Caledon Institute of Social Policy, accessed 4/21/2017 at http://www.caledoninst.org/Publications/PDF/1086ENG.pdf.

UNICEF Office of Research. 2014. 'Children of the Recession: The impact of the economic crisis on child well-being in rich countries', Innocenti Report Card 12, UNICEF Office of Research, Florence.

U.S. Government Accountability Office. 2007. Food Stamp Program. GAO-07-465. Washington, DC.

U.S. House of Representatives. 1996. "Background Material and Data on Programs within the Jurisdiction of the House Committee on Ways and Means." Committee on Ways and Means, U.S. House of Representatives, U.S. Congress, Washington, DC.

U.S. Internal Revenue Service. 2016. U.S. individual income tax public use sample. Washington, DC: Statistics of Income Division.

World Bank. 2017. "PPP Conversion Factor, GDP (LCU per international \$”. Accessed on 4/21/2017 at http://data.worldbank.org/indicator/PA.NUS.PPP.

Ziliak, James. 2016. “Temporary Assistance for Needy Families.” In Economics of MeansTested Transfer Programs in the United States, Volume I, edited by Robert Moffitt. Chicago: University of Chicago Press. 
Table 1: Average tax rates from no work to part-time and full-time work Single Mother, Two Children

Panel A-US

\begin{tabular}{|c|c|c|c|c|c|c|}
\hline \multirow{2}{*}{$\begin{array}{c}\text { Hourly Wage } \\
\% \text { of } \\
\text { minimum } \\
\text { wage }\end{array}$} & \multicolumn{3}{|c|}{1992} & \multicolumn{3}{|c|}{2015} \\
\hline & $0-->$ PT & $0-->\mathrm{FT}$ & PT --> FT & $0-->$ PT & $0-->$ FT & PT --> FT \\
\hline $100 \%$ & $64 \%$ & $53 \%$ & $42 \%$ & $-46 \%$ & $-34 \%$ & $-22 \%$ \\
\hline $125 \%$ & $68 \%$ & $51 \%$ & $35 \%$ & $-47 \%$ & $-20 \%$ & $6 \%$ \\
\hline $150 \%$ & $60 \%$ & $53 \%$ & $45 \%$ & $-43 \%$ & $-9 \%$ & $26 \%$ \\
\hline $200 \%$ & $53 \%$ & $52 \%$ & $51 \%$ & $-34 \%$ & $1 \%$ & $35 \%$ \\
\hline \multicolumn{7}{|c|}{ Panel B-Canada } \\
\hline Hourly Wage & \multicolumn{3}{|c|}{1992} & \multicolumn{3}{|c|}{2015} \\
\hline $\begin{array}{c}\% \text { of } \\
\text { minimum } \\
\text { wage }\end{array}$ & $0-->$ PT & $0-->$ FT & $\mathrm{PT}-->\mathrm{FT}$ & $0-->$ PT & $0-->$ FT & PT --> FT \\
\hline $100 \%$ & $45 \%$ & $73 \%$ & $101 \%$ & $24 \%$ & $43 \%$ & $63 \%$ \\
\hline $125 \%$ & $51 \%$ & $79 \%$ & $106 \%$ & $29 \%$ & $52 \%$ & $75 \%$ \\
\hline $150 \%$ & $59 \%$ & $83 \%$ & $106 \%$ & $34 \%$ & $52 \%$ & $70 \%$ \\
\hline $200 \%$ & $73 \%$ & $52 \%$ & $31 \%$ & $43 \%$ & $53 \%$ & $62 \%$ \\
\hline
\end{tabular}

Notes: Part-time (PT) defined as working 20 hours a week, 52 weeks a year. Full-time (FT) defined as working 40 hours a week, 52 weeks a year. Each cell shows the participation tax rate on cash and near-cash universal state/provincial and federal transfers for a hypothetical single mother with two children moving out of work into employment with wages equivalent to the 2015 minimum wage (adjusted for inflation using the CPI-U). For the US, this example scenarios faced by a single mother two children ages 4 and 6 living in Colorado. For Canada, this example illustrates scenarios for a single mother with two children younger than 18 living in Ontario. See text for details. 
Figure 1: Real per capita spending on key safety net programs

\section{Panel A-US}

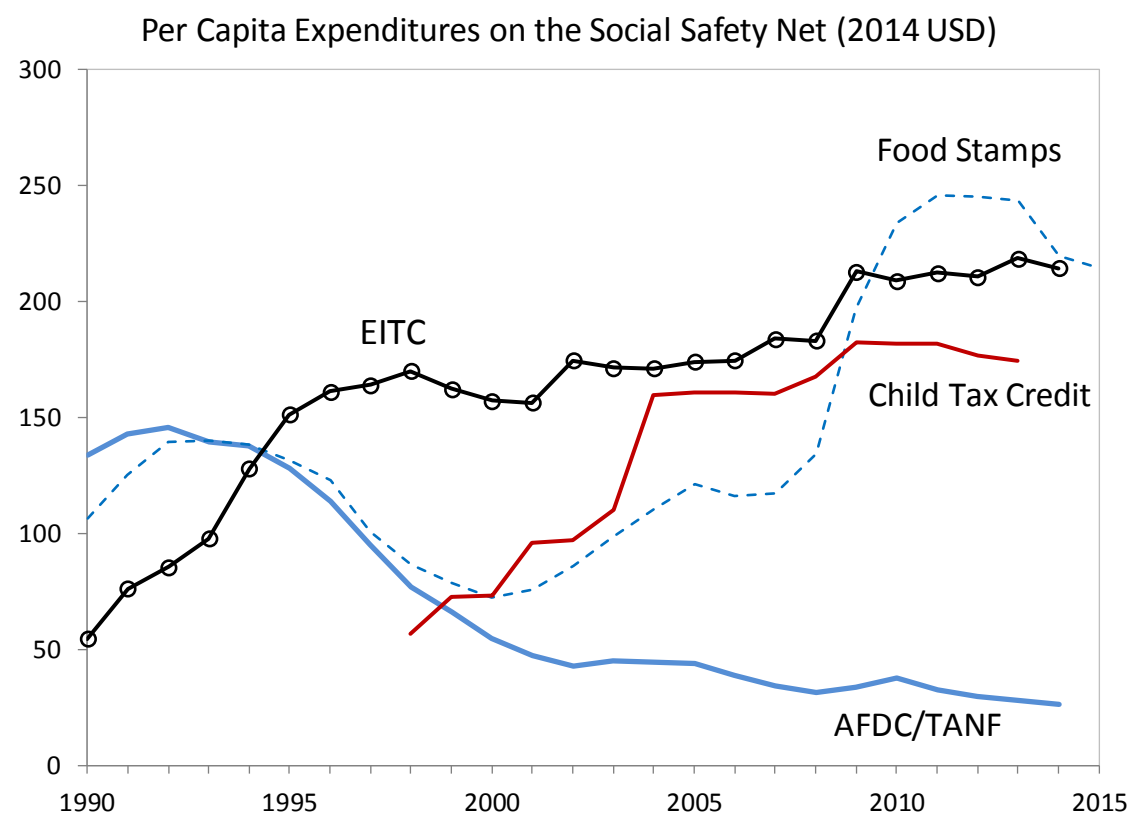

Panel B-Canada

Per Capita Social Service Spending (2014 CAN)

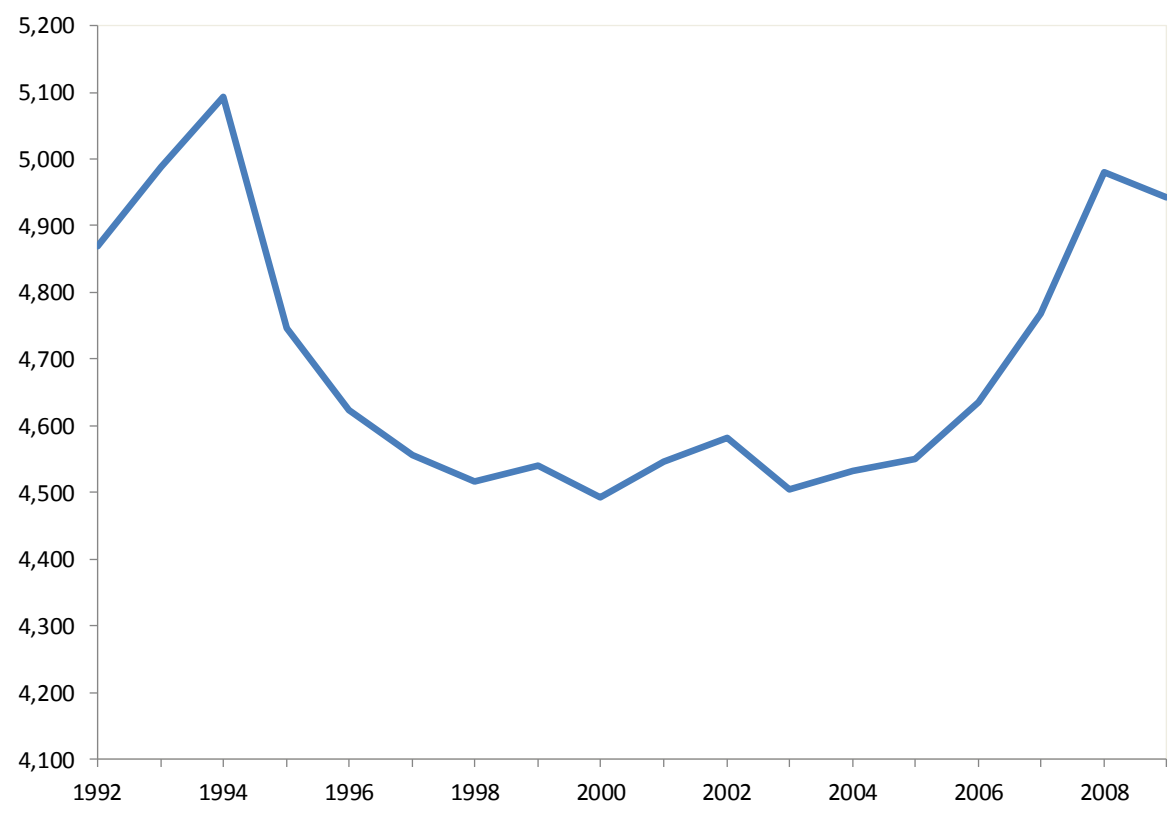

Notes: US: Total expenditures from Internal Revenue Service (EITC and CTC); Department of Agriculture (Food Stamps); and Department for Health and Human Services (AFDC/TANF). All values in 2014 dollars, adjusted by the CPI-U divided by the total population. CA: Social Service Spending from federal, provincial, territorial and local governments (Statistics Canada). All values in 2014 CAN dollars, adjusted by the CPI and divided by the total population. 
Figure 2: US budget constraint, cash and near-cash universal programs (2015\$)

Panel A: Single adult with two children, Colorado, 1992

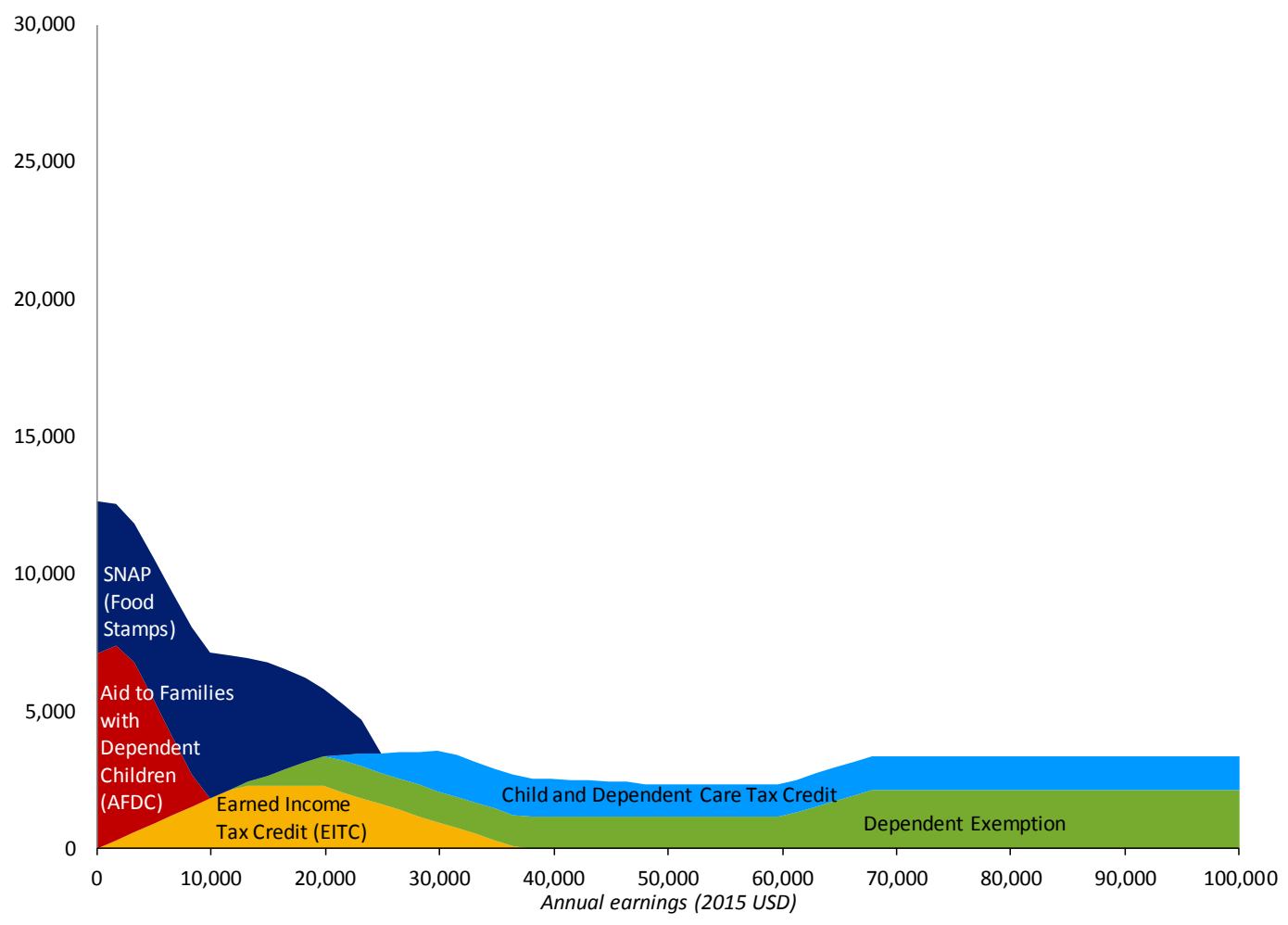

Panel B: Single adult with two children, Colorado, 2015

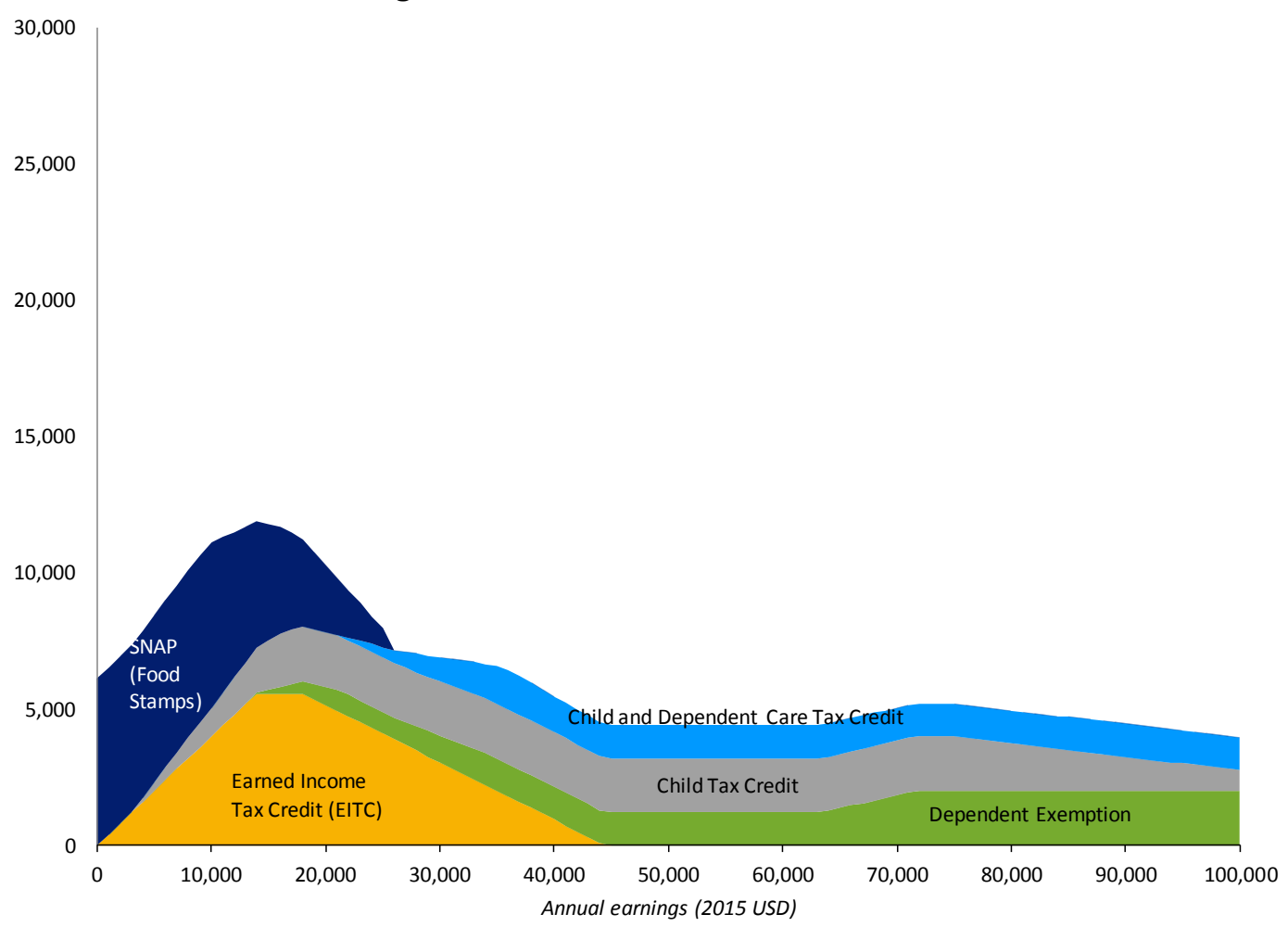

Notes: Estimated value of tax and transfer benefits for a single parent with two children living in Colorado. Program parameters from Internal Revenue Service and Tax Policy Center (EITC, CTC, Dependent Exemption, Child and Dependent Care Tax Credit) and Ways \& Means Green Book and Department of Agriculture (SNAP). Based on data from Steuerle and Quakenbush (2015). 
Figure 3: Canada budget constraint, cash and near-cash universal programs

Panel A: Single adult with two children, Ontario, 1992

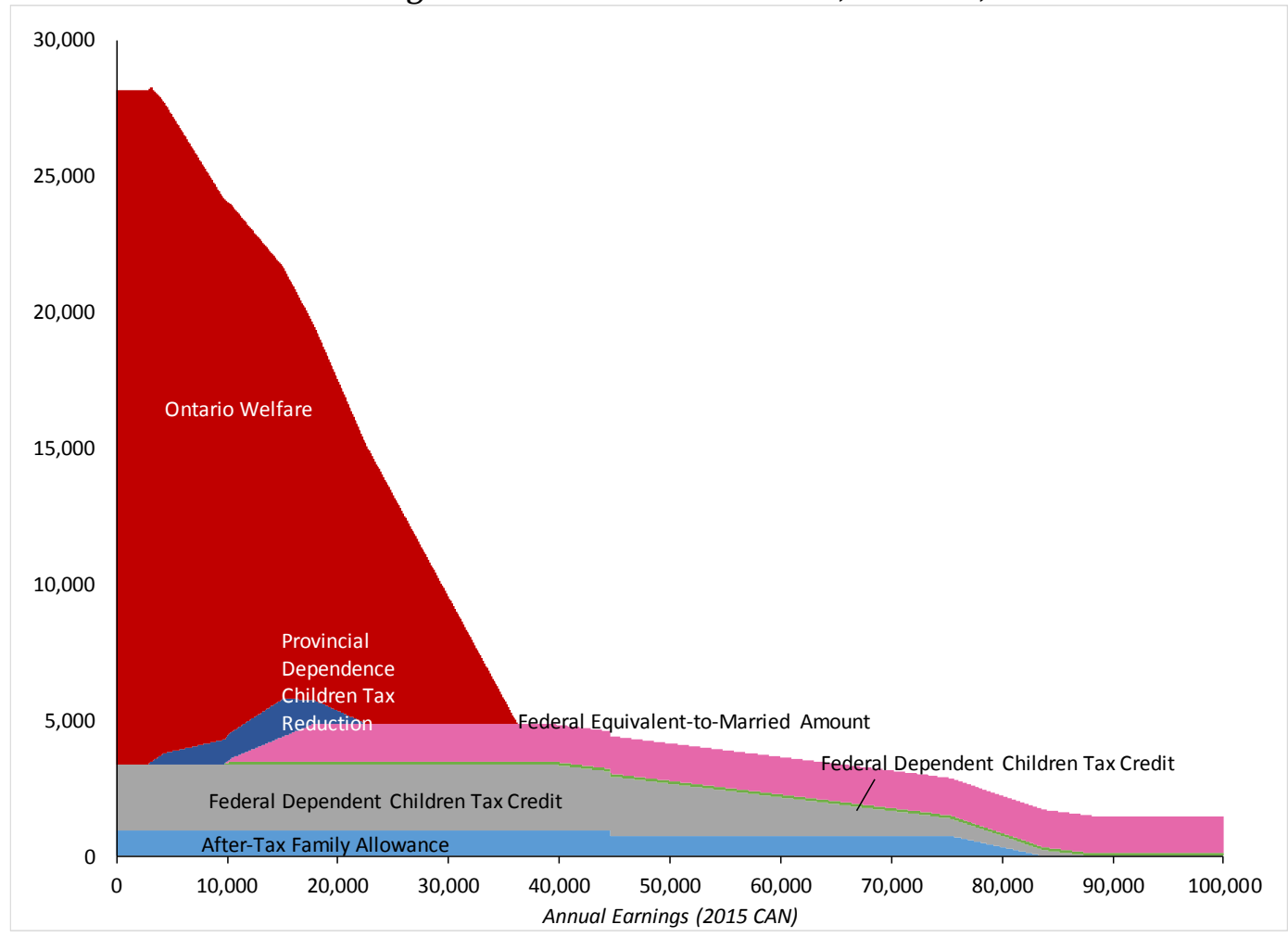

Panel B: Single adult with two children, Ontario, 2015

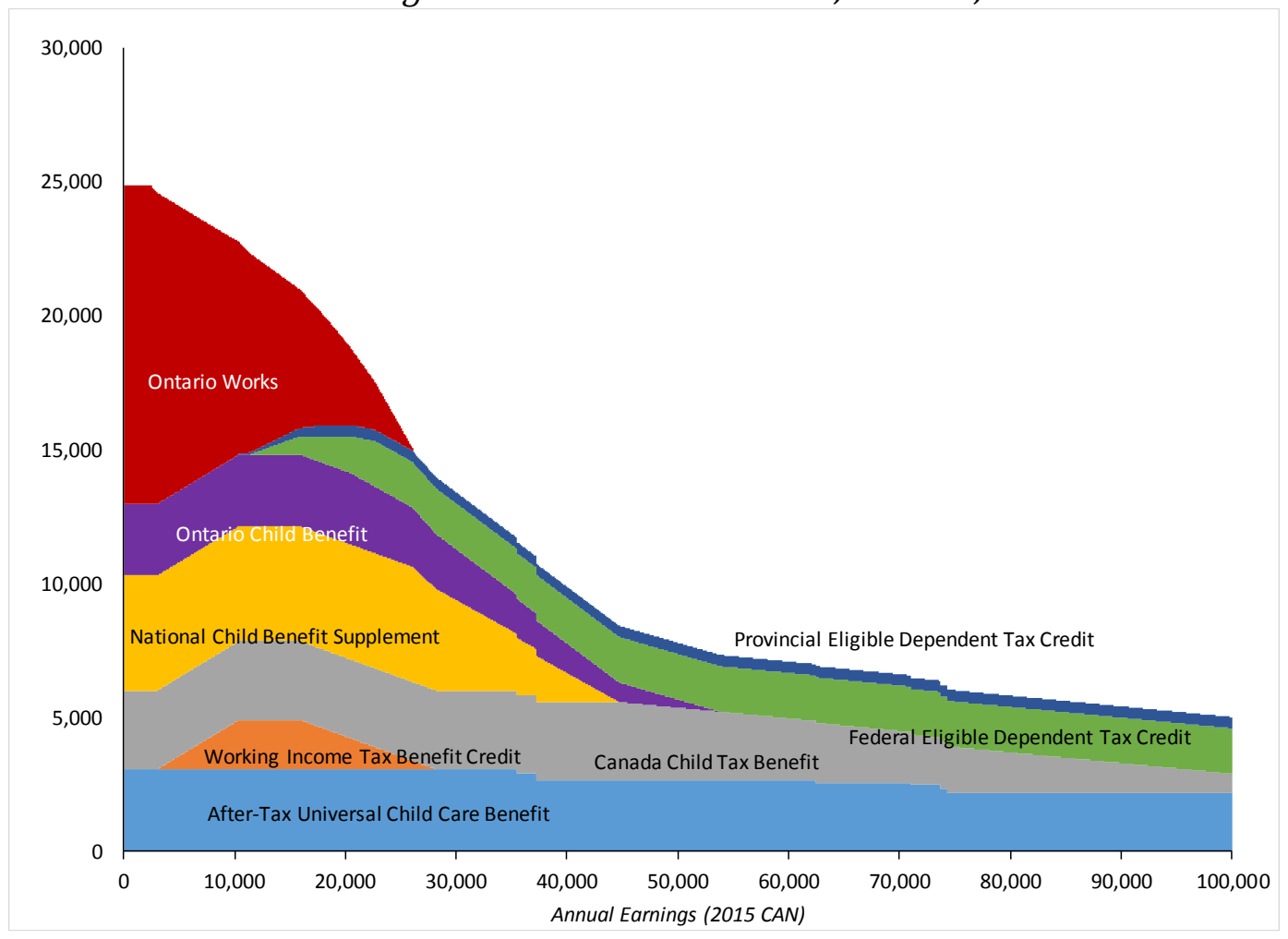

Notes: Estimated value of major tax and transfer programs for a single parent family with two children in the province of Ontario in real (2015) CDN dollars. Program parameters from Department of Finance, Canada and the Ontario Ministry of Finance. 


\section{Figure 4:}

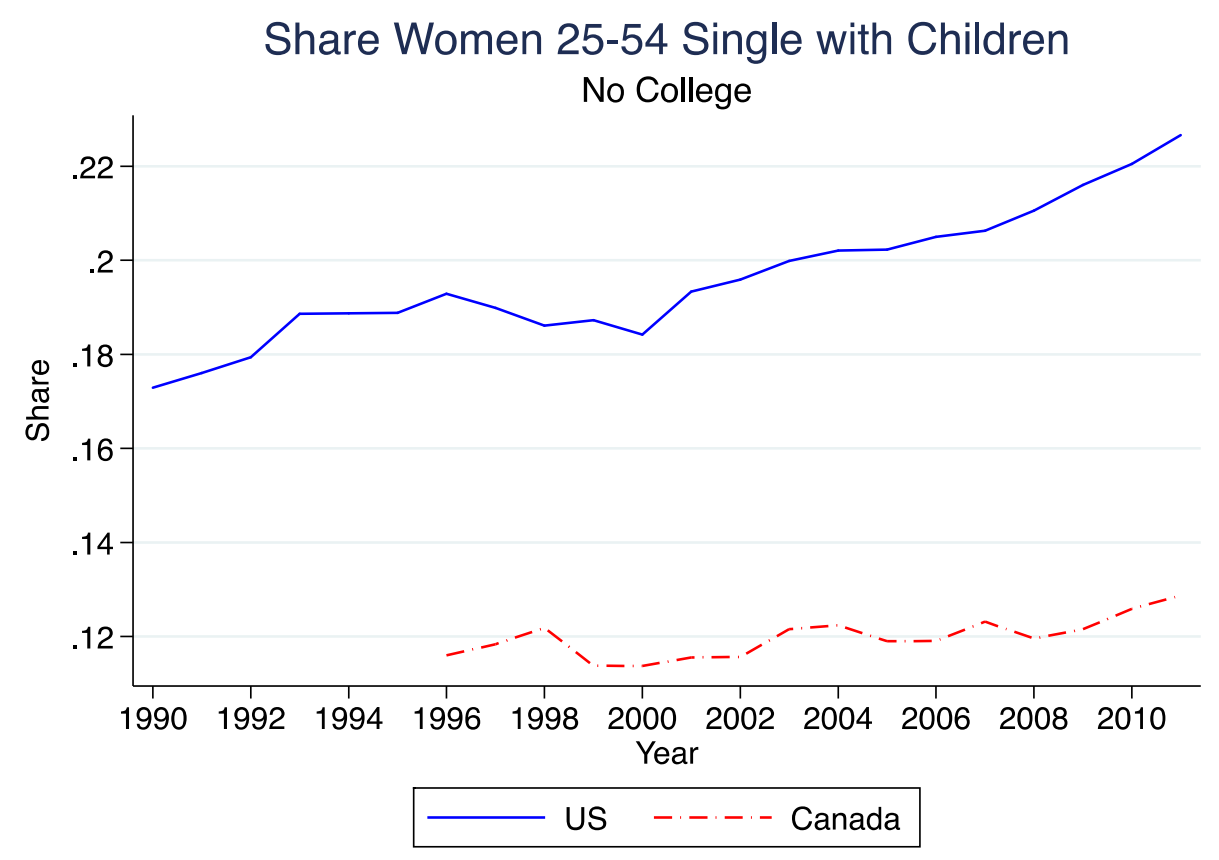

Notes: No college defined as less than a four-year degree. Data from Current Population Survey, Annual Social and Economic Supplement (US), and Survey of Labour and Income Dynamics (CA). Sample includes women $25-54$. 


\section{Figure 5:}

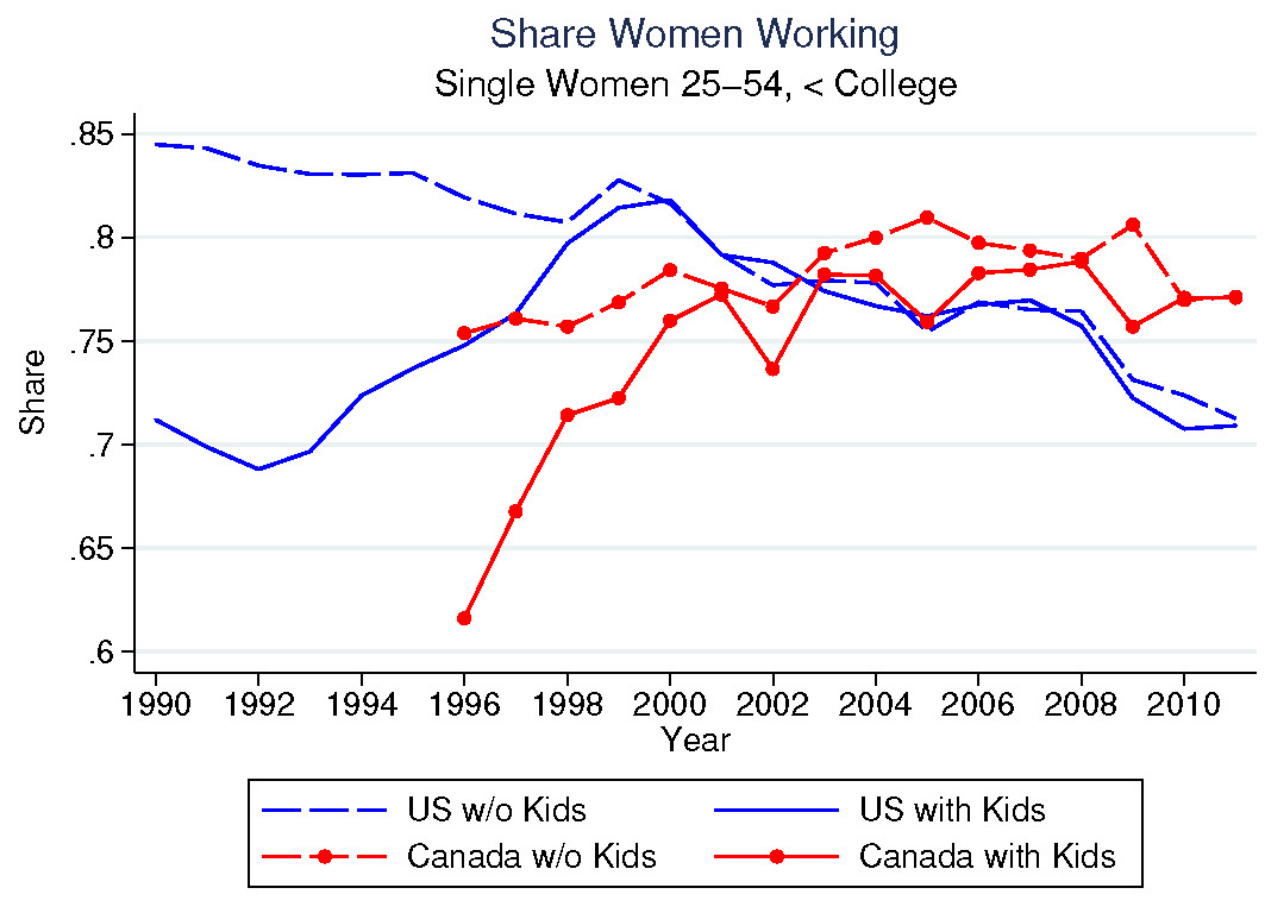

Notes: No college defined as less than a four-year degree. Women are considered working if they worked at least one week in the previous year. Data from Current Population Survey, Annual Social and Economic Supplement (US), and Survey of Labour and Income Dynamics (CA). Sample includes women 25-54.

\section{Figure 6:}

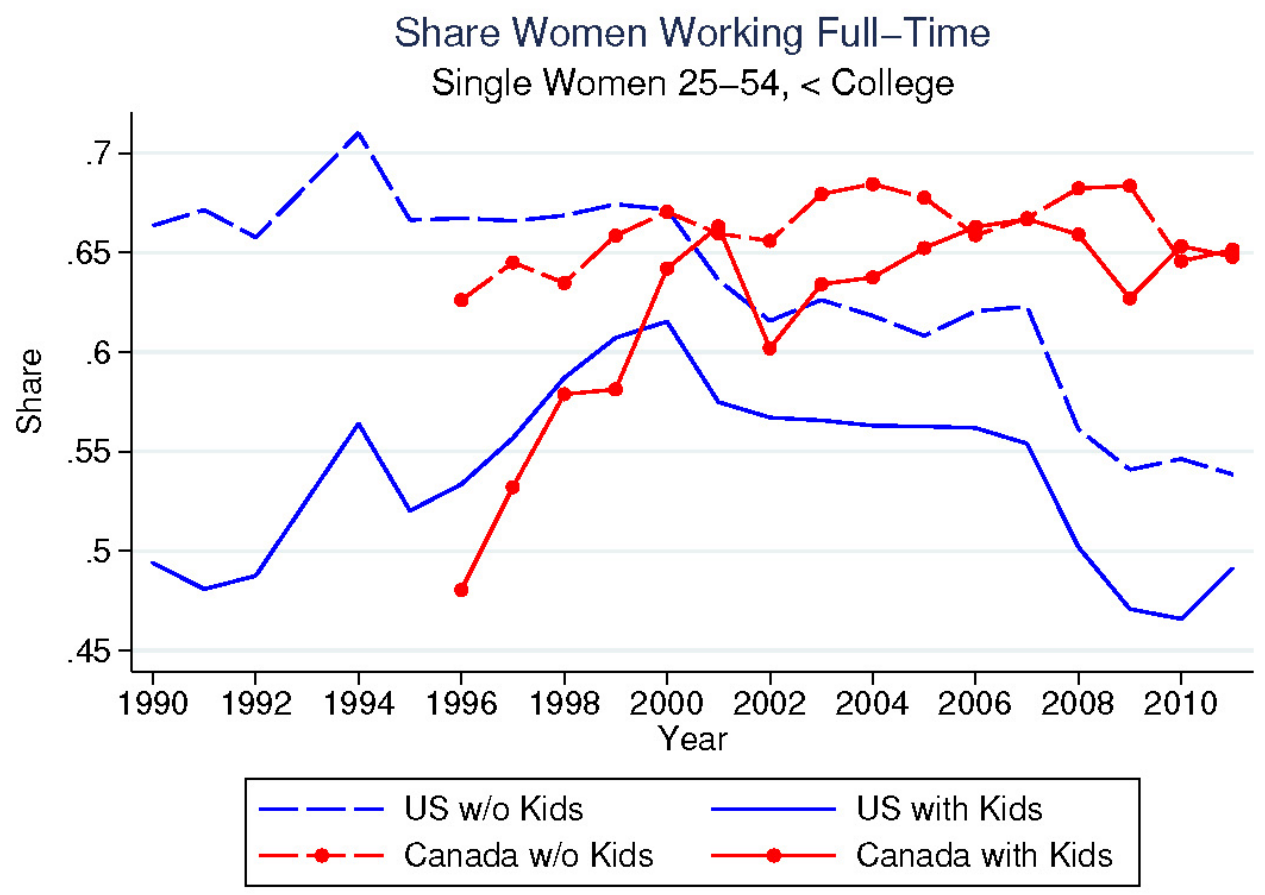

Notes: No college defined as less than a four-year degree. Women are considered working full-time if they reported usually working at least 35 hours a week and at least 50 weeks in the previous year. Data from Current Population Survey, Annual Social and Economic Supplement (US), and Survey of Labour and Income Dynamics (CA). Sample includes women 25-54. 


\section{Figure 7:}

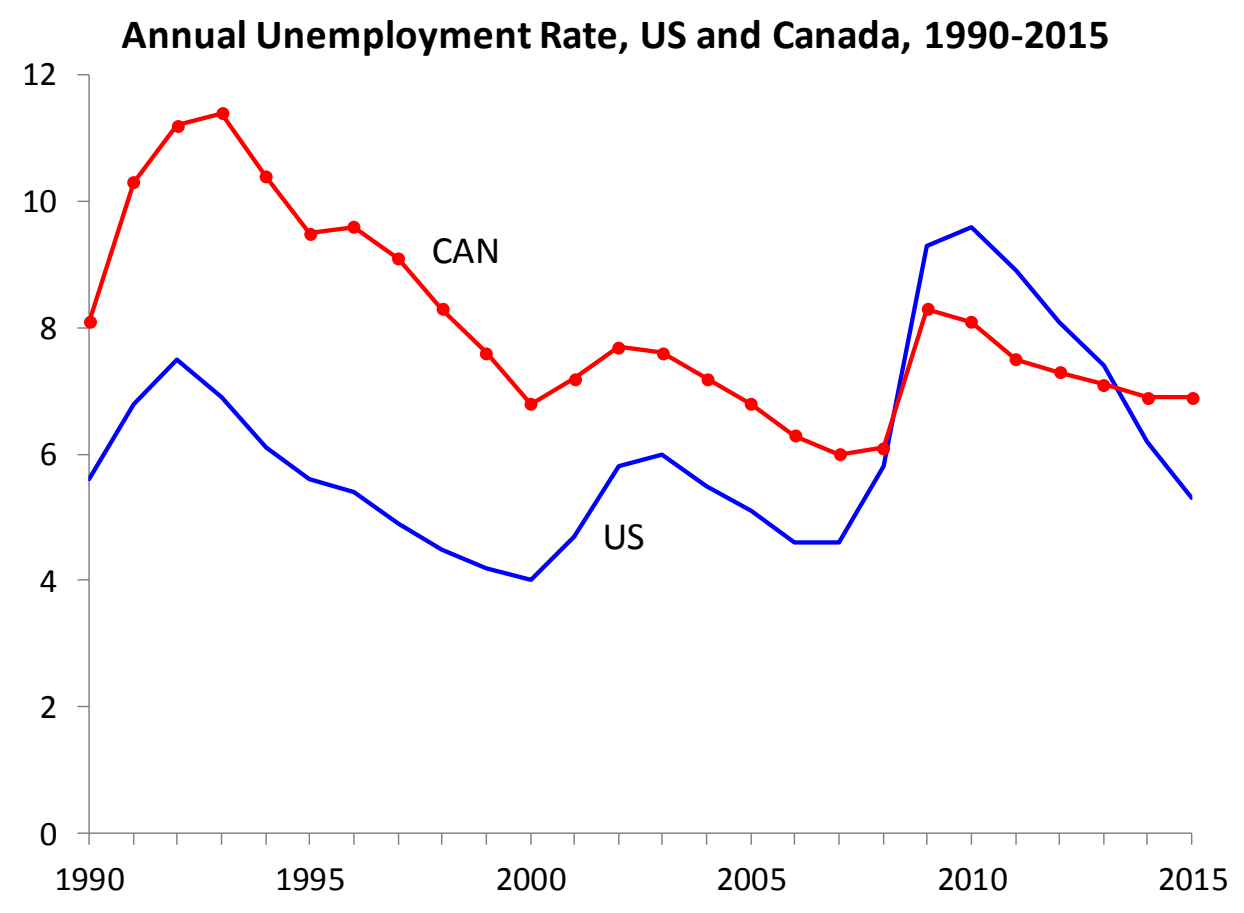

Notes: Figure presents annual unemployment rate. Data from Bureau of Labor Statistics and Statistics Canada, Labour Force Survey (CA). 


\section{Figure 8:}

Share in Country-Specific Absolute Poverty (ATT Income)

Single Women 25-54, < College, base year 1996

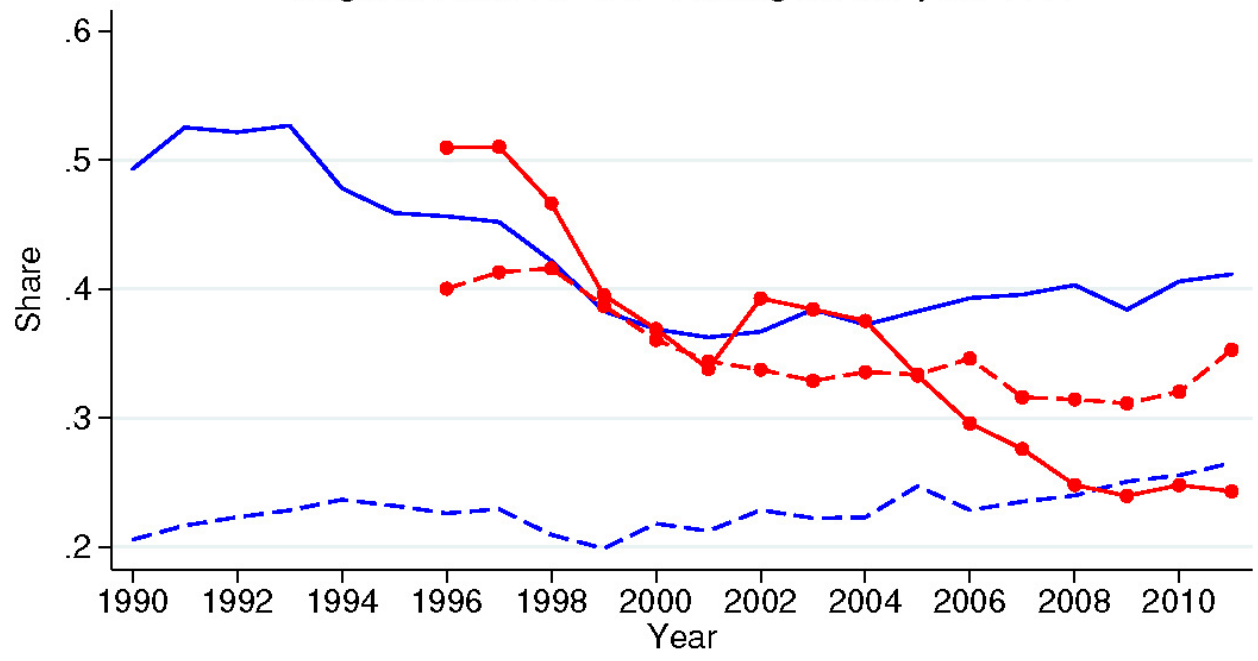

$$
\begin{array}{|ll}
---- \text { US w/o Kids } & \text { US with Kids } \\
---- \text { Canada w/o Kids } \longrightarrow \text { Canada with Kids }
\end{array}
$$

Notes: No college defined as less than a four-year degree. Absolute poverty defined as 60 percent of the median equivalized after tax and transfer (ATT) income in 1996 for each country, adjusted for inflation. See text for details. Data from Current Population Survey, Annual Social and Economic Supplement (US), and Survey of Labour and Income Dynamics (CA). Sample includes single women 25-54.

\section{Figure 9:}

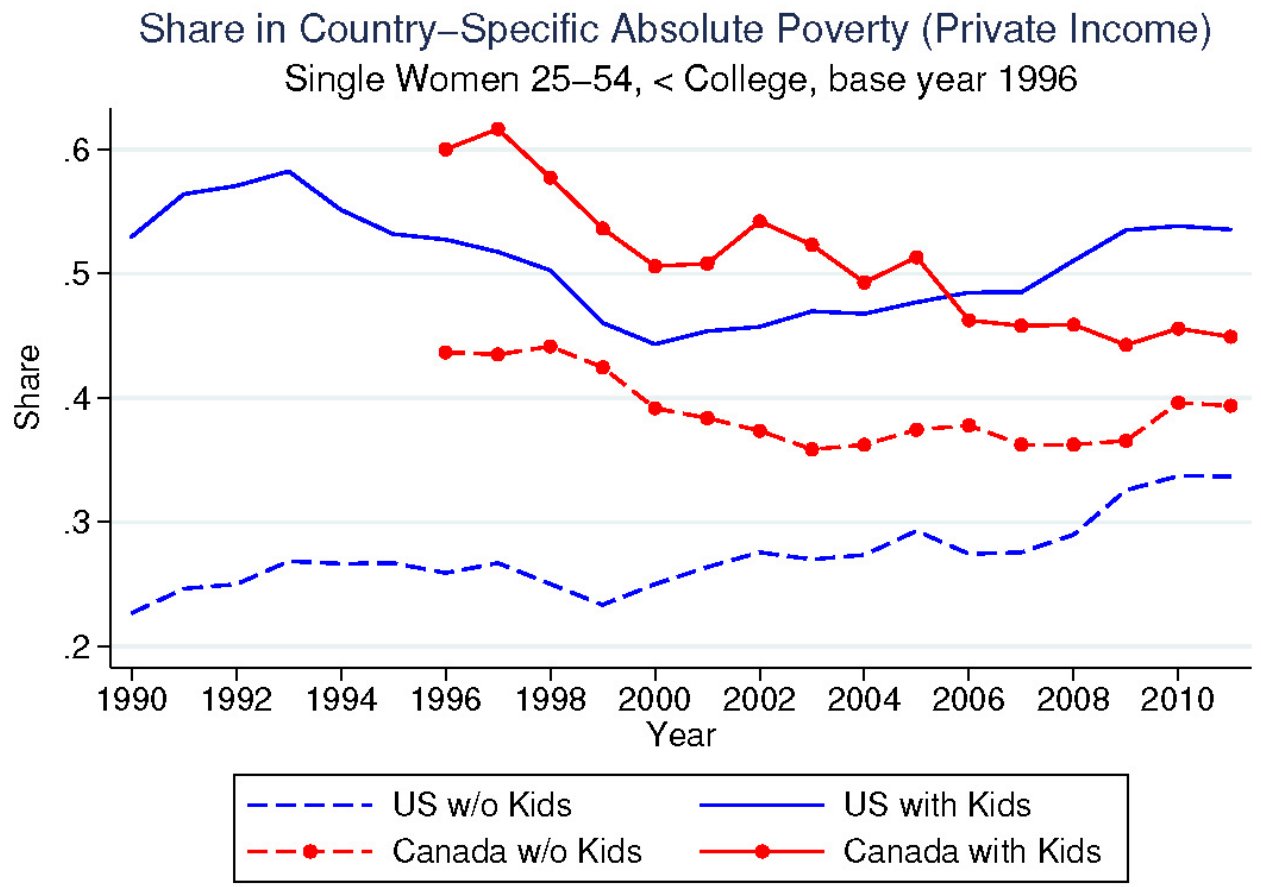

Notes: No college defined as less than a four-year degree. Absolute poverty defined as 60 percent of the median equivalized after tax and transfer (ATT) income in 1996 for each country, adjusted for inflation. See text for details. Data from Current Population Survey, Annual Social and Economic Supplement (US), and Survey of Labour and Income Dynamics (CA). Sample includes single women 25-54. 


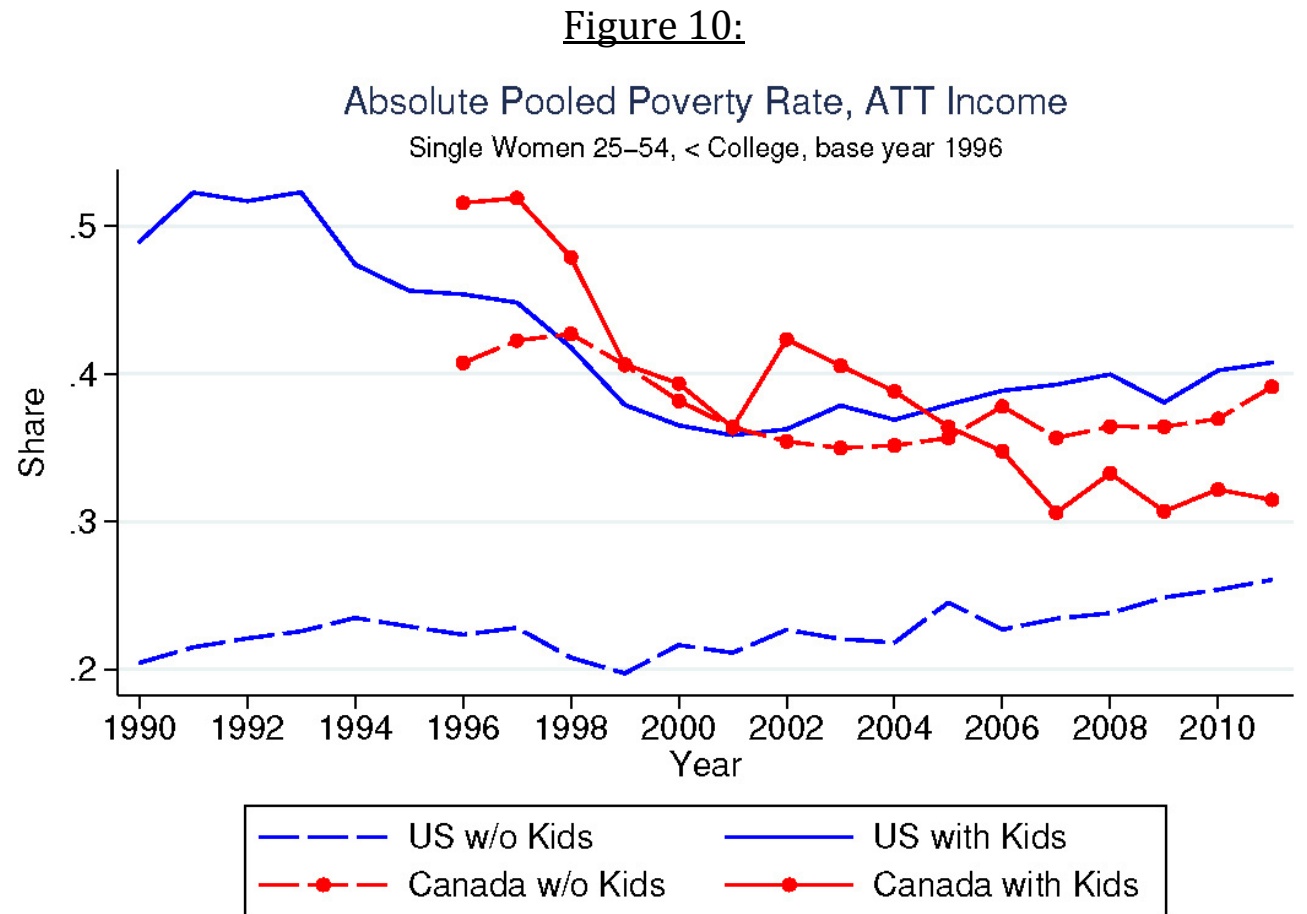

Test for equality between 2011 poverty rates for women with and without children: Canada $\mathrm{t}=-2.931$, US $\mathrm{t}=13.073$

Notes: No college defined as less than a four-year degree. The absolute poverty threshold is defined as 60 percent of the median equivalized ATT income for US and Canada combined in 1996, adjusted for inflation. The same threshold is used for private income poverty and ATT poverty, the measures differ only in what resource measure is used. See text for details. Data from Current Population Survey, Annual Social and Economic Supplement (US), and Survey of Labour and Income Dynamics (CA).

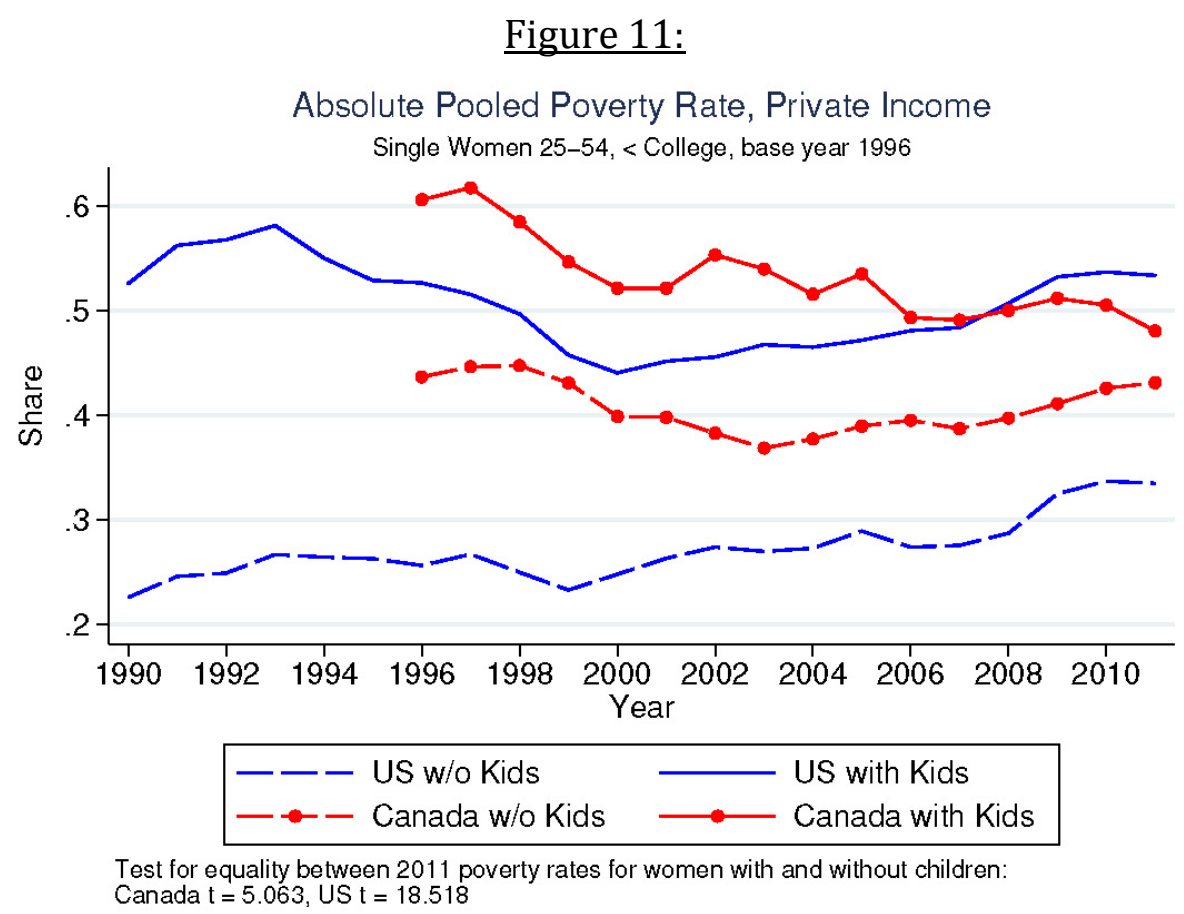

Notes: No college defined as less than a four-year degree. The absolute poverty threshold is defined as 60 percent of the median equivalized ATT income for US and Canada combined in 1996, adjusted for inflation. The same threshold is used for private income poverty and ATT poverty, the measures differ only in what resource measure is used. See text for details. Data from Current Population Survey, Annual Social and Economic Supplement (US), and Survey of Labour and Income Dynamics (CA). 
Figure 12: Relative employment trends, using pooled country data (base year 1996)

\section{Employment}

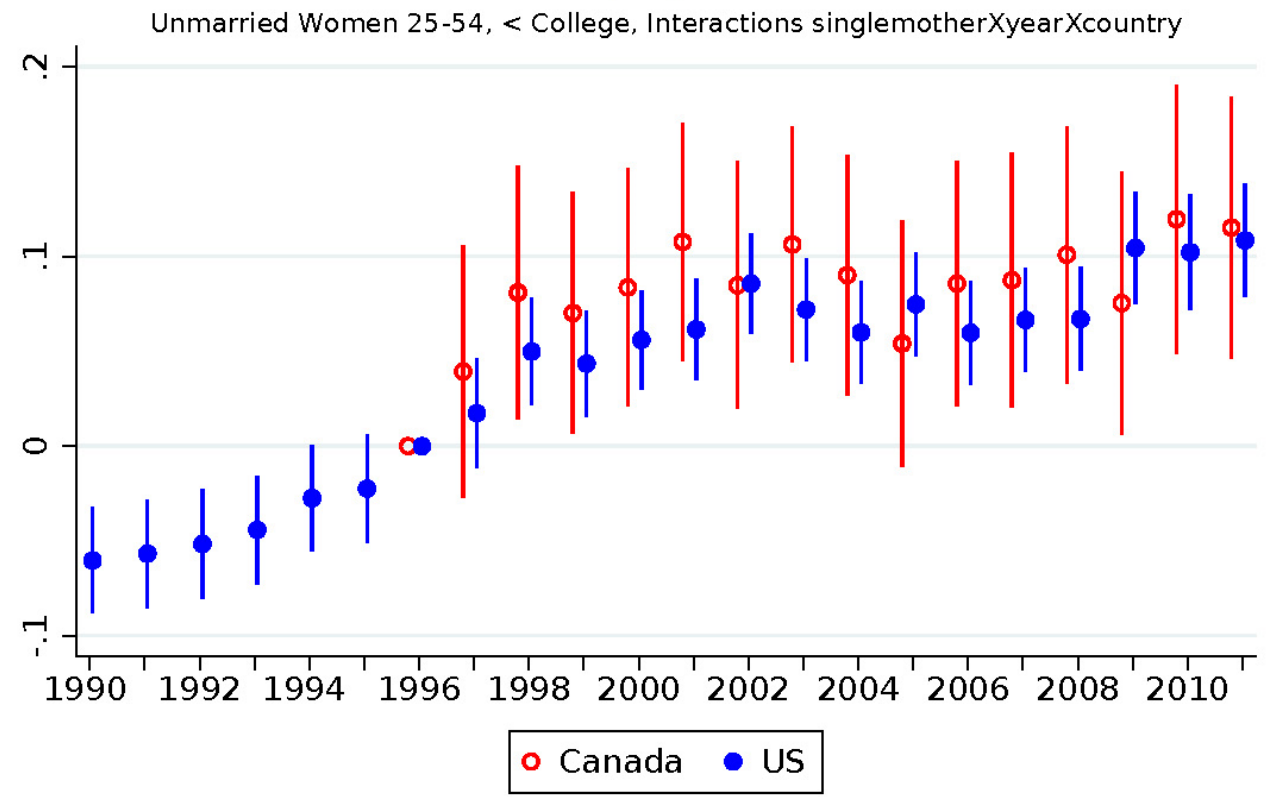

Joint F-test: $F=.678, p=.8085$

Notes: Figure plots the coefficients on the interaction between single mother*year for each country for regressions of employment on fixed effects for year*country, province/state unemployment rates, single mother, single mother*year. Sample combines the 1990 through 2011 from the CPS and 1996 through 2011 from the SLID and consists of all unmarried women ages 25 to 54 with less than college degree. Test statistics of joint hypothesis of equality between the US and Canadian interactions displayed below each graph. 
Figure 13: Absolute pooled ATT poverty using pooled cross country data (base year 1996)

Absolute Pooled Poverty, ATT Income

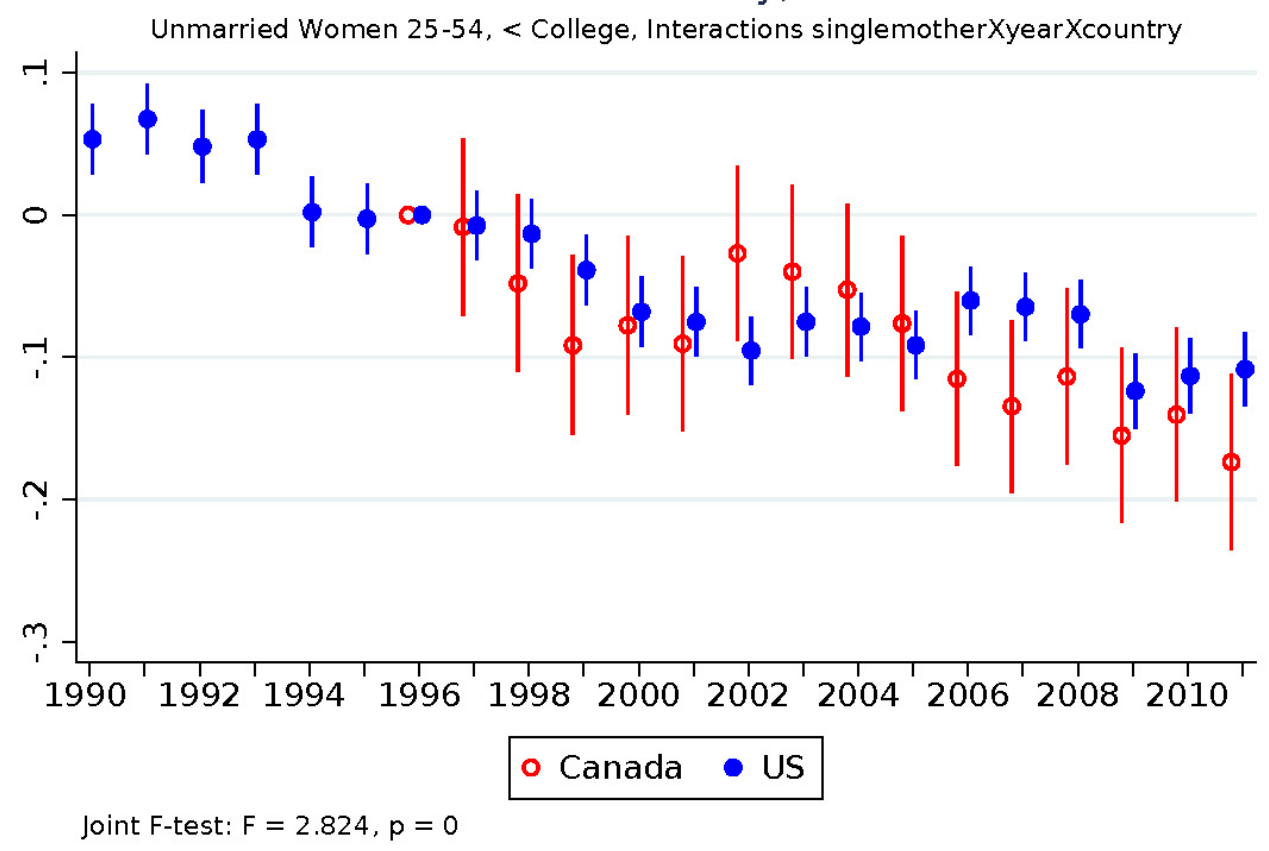

Figure 14: Absolute pooled private income poverty using pooled cross country data (base year 1996)

Absolute Pooled Poverty, Private Income

Unmarried Women 25-54, < College, Interactions singlemotherXyearXcountry

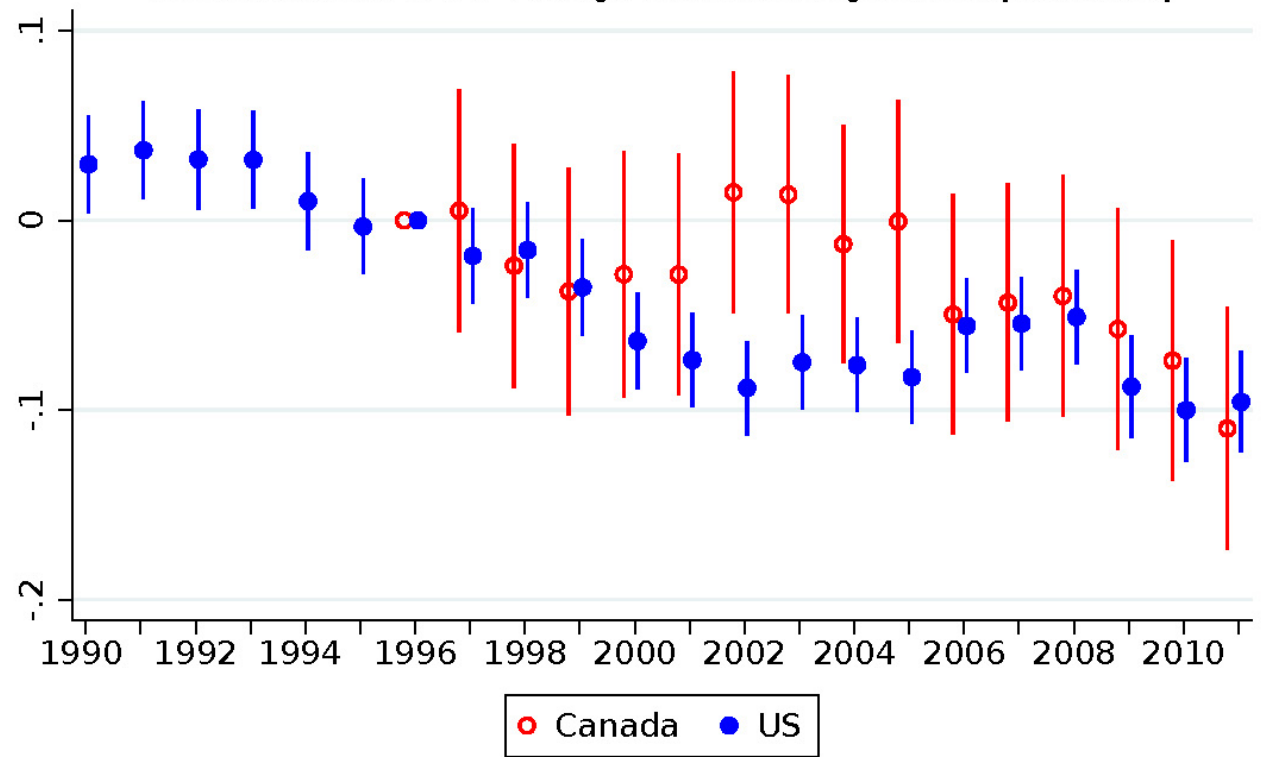

Joint F-test: $F=2.263, p=.003$

Notes to Figures 13-14: Figure plots the coefficients on the interaction between single mother*year for each country for regressions of poverty on fixed effects for year*country, province/state unemployment rates, single mother, single mother*year. Sample combines the 1990 through 2011 from the CPS and 1996 through 2011 from the SLID and consists of all unmarried women ages 25 to 54 with less than college degree. Test statistics of joint hypothesis of equality between the US and Canadian interactions displayed below each graph. 
Appendix A: changes in social safety net and provincial programs, Canada ${ }^{23}$

\section{TAX BASED BENEFITS}

Federal:

The Canada Child Tax Benefit pays $\$ 1,446$ per child in 2014-15. For family net income over $\$ 43,953$ it is phased out at a rate of $2 \%$ for one child; $4 \%$ when there are two or more children. The benefit amounts and thresholds have been updated annually since 1997 for inflation, but otherwise not changed.

The National Child Benefit Supplement began in 1998. The rates for 2014-15 are $\$ 2,241$ for the first child, $\$ 1,982$ for the second, and $\$ 1,886$ for the third. The benefits are phased out sharply at rates of $12.2 \%, 23.0 \%$, and $33.3 \%$ for incomes over $\$ 25,584$. It is indexed annually for inflation. There were substantial additional increases in several years. Between 1998 and 2001 the benefit levels more than doubled. There were also increases of $13 \%$ in 2003, 14\% in 2005, and $13 \%$ in 2006.

The Universal Child Care Benefit began in 2006. It pays $\$ 100$ per month for each child under age 6 and is taxable in the hands of the lower income spouse.

The Working Income Tax Benefit began in 1997. It pays $\$ 500$ to families with children, phased in with income over $\$ 3,750$ and then phased out for income over $\$ 20,921$. It was removed when the National Child Benefit Supplement was introduced in 1998. In 2007, the Working Income Tax Benefit began payments to adults. There was no supplement for children in this benefit. The amount for singles in 2014 is \$998, with couples getting $\$ 1813$. There are some differences across provinces, but for most provinces it is phased in at $25 \%$ for income over $\$ 3,000$, and phased out at $15 \%$ starting at $\$ 11,332$ for singles and $\$ 15,649$ for couples. For singles, it is completely phased out by $\$ 18,000-$ so this benefit is very narrowly targeted.

Newfoundland and Labrador:

The Newfoundland Child Benefit was introduced in 1999 and is paid monthly. In 2014 , the annual rate for a first child was $\$ 369, \$ 392$, for a second child, $\$ 421$ for a third child, and $\$ 451$ for a fourth child. The clawback of these benefits was in the income range $\$ 17,397$ to $\$ 21,480$. Increases through time followed inflation, except for a $25 \%$ increase to the one-child rate in 2007. An additional supplement for children age zero was added in 2001.

Prince Edward Island:

No child benefit program.

Nova Scotia:

The Nova Scotia Child Benefit started in 1998 and is paid monthly. In 1998, the payments ranged from $\$ 250$ for the first child to $\$ 136$ for a third (or higher) child. In 2001, the payments for third and higher children increased substantially. In 2005, the payment rates were $\$ 445$ annually for a first child, $\$ 645$ for a second, and $\$ 720$ for a third. These benefits are clawed back at high clawback rates for incomes over $\$ 16,000$. Nova Scotia does not update the benefit for inflation.

In 2010, the Affordable Living Tax Credit was introduced with a base benefit of $\$ 240$ augmented by $\$ 57$ per child. This is phased out at 5\% for income over $\$ 30,000$. New Brunswick:

The New Brunswick Child Tax Benefit was introduced in 1997, before the national NCB program reached its starting point. The annual benefit is $\$ 250$ per child paid monthly,

23 This appendix draws heavily on Milligan, and Stabile (2011). 
and has not changed since 1997 . The benefit is clawed back at $2.5 \%$ or $5 \%$ for family net income over $\$ 20,000$. In addition, there is a Working Income Supplement of $\$ 250$ annually that is phased in at $4 \%$ for earned income over $\$ 3,750$ and clawed back at a rate of $5 \%$ for family net income over $\$ 20,921$. These amounts have been the same since 1997 with no updates for inflation.

Quebec:

Until 1997, residents of Quebec were eligible for a family allowance, an allowance for young children, and an allowance for newborn children. These amounts increased with the number of children in the family and did not depend on family income. In 1997, these were combined into a new family allowance. The rates for the new family allowance were $\$ 2,275$ per child for a single parent family and $\$ 975$ per child for a two-parent family. These amounts were clawed back starting at incomes of \$15,332 for singles and \$21,825 for two-parent families. However, the clawback only took benefits down to a minimum benefit level that was $\$ 80$ annually for one and two child families and $\$ 975$ for three child families. But, for those with family net incomes higher than $\$ 50,000$ these 'minimum' benefits were clawed back at a rate of $5 \%$. In Quebec there was also an earned income benefit called APPORT in place from 1988 to 2004. In 2004, this benefit was phased in for earnings over $\$ 1,200$ at a rate of $35 \%$ until an earnings level of $\$ 11,370$ (two-parent) or $\$ 7,790$ (one-parent), and then clawed back at $43 \%$ after that. At the peak benefit level the benefit amount was quite large, but take-up of this benefit was not high. In 2005 a new Child Assistance program replaced the family allowance. The Child Assistance benefit in 2014 was $\$ 2,341$ for the first child, $\$ 1,170$ for the second and third children, and \$1,755 for the fourth or higher child. The phaseout rate is $4 \%$ for incomes over $\$ 33,944$ (single) or $\$ 46,699$ (couple). The amounts have been updated annually for inflation. Benefit distribution defaults to a quarterly schedule, although families can opt to receive the benefit monthly.

Also in 2005, a new Work Premium replaced APPORT. It is phased in for incomes over $\$ 2,400$ (single) or $\$ 3,600$ (couple) at $25 \%$ (couples) and $30 \%$ (single). After a 'turnaround' point, it is phased out at a rate of $10 \%$. The turnaround point is $\$ 10,286$ (singles) or $\$ 15,914$ (couples).

Ontario:

Ontario introduced the Ontario Child Care Supplement for Working Parents in 1997, and renamed as the Ontario Child Benefit in 2007. It pays out monthly. The initial rates were $\$ 400$ per child age 0 to 6 , clawed back at $4 \%$ for net family income over $\$ 20,000$. In 1998 , the amounts were revamped and largely stayed the same until 2005 . From 1998 , the amount was phased in with earned income over $\$ 5000$, at a rate of $20 \%$ for 1998 and $21 \%$ from 1999 to 2005 . The 2014 benefit amount was $\$ 1,100$ per child age 0 to 6 for a oneparent family and $\$ 1310$ for a two-parent family. The clawback rate was $8 \%$ for incomes over $\$ 20,000$. These amounts did not change between 1999 and 2014, with no adjustments for inflation. In 2010, a new Sales Tax Credit was introduced, paying \$260 per member of the family; phased out with income over $\$ 25,000$ at a rate of $4 \%$.

Manitoba:

Manitoba ran its own child benefit program called CRISP until 2008. In 2008, CRISP paid $\$ 360$ annually per child, with a clawback rate of $2.083 \%$ for incomes over $\$ 12,384$. These amounts had not changed in nominal terms since the 1980s.

Starting in 2009, a new Manitoba Child Benefit was introduced, with a rate of $\$ 420$ per child, clawed back after income of $\$ 15,000$ at rates of $7.73 \%, 15.46 \%$, and $23.18 \%$ for families of one, two, and three or more children respectively. The amounts have not been updated for inflation. 
Saskatchewan:

The Saskatchewan Child Benefit was introduced in 1998. In the first year, it paid $\$ 900$ annually to a one child family, $\$ 1,104$ for a second child, and $\$ 1,176$ for a third. It is clawed back at high rates for family net incomes over $\$ 15,921$. As the NCBS increased in the following years, the Saskatchewan Child Benefit was decreased downward dollar for dollar, so that by 2005 it paid only $\$ 7$ annually for a 2 nd child and $\$ 86$ for a third. It was cancelled in 2006.

Additionally, there is a working income supplement in Saskatchewan. In 2005 the amount ranges from $\$ 2,385$ for a one child family to $\$ 4,293$ for a five child family. It is phased in for earnings over $\$ 1,500$ at rates between $25 \%$ and $45 \%$ and clawed back at a $20 \%$ rate for incomes over $\$ 14,640$. There is a supplement for children under age 13 that pays an extra $25 \%$ on top of the regular employment supplement. These amounts have not been updated for inflation through time.

In 2000, Saskatchewan introduced the Saskatchewan Low Income Tax Credit, paying $\$ 77$ for each adult and $\$ 55$ for each child. It was clawed back at $1 \%$ for incomes that varied with family type. The amounts increased to $\$ 100$ and $\$ 75$ in 2003 , then $\$ 216$ and $\$ 84$ in 2008. The phased out rate was increased to $2 \%$, and all family types faced the same threshold of $\$ 28,335$. These amounts have been updated annually for inflation and it is paid quarterly.

Alberta:

Alberta has an employment-related child benefit that is paid monthly. It was introduced in 1997 with a phase-in rate of $8 \%$ for earnings over $\$ 6,500$ up to a maximum of $\$ 250$ for one child and $\$ 500$ for two or more. The benefit is clawed back at a rate of $4 \%$ for incomes over $\$ 25,000$. Between 1998 and 2004, the benefit maximum was set at $\$ 500$ for one child and $\$ 1000$ for two or more children, but was otherwise similar to 1997. The benefit changed again for the 2005 year. The new rates were $\$ 550$ for one child, $\$ 500$ for two children, $\$ 300$ for three children, and $\$ 100$ for four. These amounts were phased in at $8 \%$ for earnings over $\$ 2,760$, and then phased out on incomes of $\$ 25,000$ or more at a rate of $4 \%$. These amounts have been updated for inflation each year since 2005 . British Columbia:

The BC Family Bonus was introduced in 1996, two years before the NCB program, and is paid monthly. The Bonus rate was $\$ 1,236$ per child and was clawed back at a rate of $8 \%$ for one child and $16 \%$ for two or more for incomes higher than $\$ 18,000$. These amounts were increased to $\$ 1,332,9 \%, 18 \%$, and $\$ 20,500$ in 2001 and have remained constant since. However, the NCBS is subtracted from the BC Family Bonus, rendering it to zero by 2005 since the NCBS is now larger than the prescribed BC Family Bonus payments. There is also a BC Earned Income Benefit that was introduced in 1998. It pays differing amounts for each child and is phased in between earnings levels of $\$ 3,750$ and $\$ 10,000$. It is clawed back for incomes higher than $\$ 20,921$ at high rates. The amounts for 2005 are $\$ 365$ for the first child, \$370 for the second, and \$372 for the third or higher. Until 2003, the amount for the first child was $\$ 605$, with $\$ 405$ for the second and $\$ 330$ for the third. After 2003, the BC Earned Income Benefit was diminished as the NCBS grew, leading it to zero by 2013.

\section{SOCIAL ASSISTANCE}

Income support is provided by provincial/territorial governments in all 13 provinces and territories. The eligibility criteria differs by jurisdiction. In 2013, for example, the basic welfare cut-off income for a single employable individual ranged 
between $\$ 6,807$ (NB) and $\$ 10,876$ (SK), and the basic welfare cut-off income for a couple with two children ranged between $\$ 20,724$ (NB) and $\$ 26,690$ (PEI) (Tweddle et al., 2014). The benefit amount also differs by jurisdiction, and is generally tied to the family status, income level, and financial need of the individual or family. For single employable individuals, the basic welfare income provided by the province/territory ranges from $\$ 6,807$ (NB) to $\$ 17,343(\mathrm{YK})$, and for a couple with two children, the basic welfare income ranges from $\$ 20,724$ (NB) to $\$ 37,733$ (YK) (Tweddle et al., 2014). ${ }^{24}$

In British Columbia, Alberta, Saskatchewan, Ontario, Quebec, New Brunswick, and Prince Edward Island, a separate social assistance program provides benefits for individuals with a disability (Tweddle et al., 2015). In all provinces and territories, with the exception of Newfoundland and Labrador, additional social assistance benefits are provided in some form - either through a higher benefit as part of their general social assistance program, or through separate program directed to individuals with disabilities (Tweddle et al., 2014).

\section{Appendix B: Data Appendix}

United States: We use the CPS to construct private income (PI) poverty and after-tax-andtransfer (ATT) poverty. Private income includes earned income, asset income, and private transfers (child support, alimony, private disability and retirement). After-tax-and-transfer resource measure, developed in Bitler and Hoynes $(2010,2015)$, includes private income plus cash transfers (AFDC/TANF, Social Security, SSI, Unemployment Compensation, veterans payments and workers' compensation), the cash value (as reported by the household or imputed by the Census Bureau) of non-cash in-kind programs (food stamps/SNAP, school lunch, housing subsidies, and energy subsidies), tax credits (the EITC, child tax credits, and stimulus payments) and then subtracts payroll, federal, and state income taxes. We use the NBER TAXSIM model for all tax variables.

Canada: We use SLID income variables to construct private income (PI) poverty and aftertax-and-transfer (ATT) poverty. SLID’ s market income variable (private income) includes earnings, investment income, private retirement pensions and support payments received, such as alimony and child support. Moreover, SLID’ s after-tax (and after-transfers) income variable is defined by total income before taxes (market income plus federal and provincial government transfers) minus federal and provincial income tax.

24 The welfare income for Nunavut is actually the lowest of all the provinces or territories, but the vast majority of social assistance recipients reside in public housing, and have housing, and many other costs, covered. 
Appendix Table 1: Average tax rates from no work to part-time and full-time work Single Individual, No Children

Panel A-US

\begin{tabular}{|c|c|c|c|c|c|c|}
\hline \multirow{2}{*}{$\begin{array}{c}\text { Hourly wages } \\
\% \text { of } \\
\text { minimum } \\
\text { wage }\end{array}$} & \multicolumn{3}{|c|}{1992} & \multicolumn{3}{|c|}{2015} \\
\hline & $0-->$ PT & $0-->$ FT & PT $-->$ FT & $0-->$ PT & $0-->$ FT & $\mathrm{PT}-->$ FT \\
\hline $100 \%$ & $14 \%$ & $34 \%$ & $54 \%$ & $-6 \%$ & $12 \%$ & $30 \%$ \\
\hline $125 \%$ & $18 \%$ & $34 \%$ & $50 \%$ & $-4 \%$ & $11 \%$ & $27 \%$ \\
\hline $150 \%$ & $23 \%$ & $34 \%$ & $44 \%$ & $2 \%$ & $10 \%$ & $17 \%$ \\
\hline $200 \%$ & $34 \%$ & $33 \%$ & $33 \%$ & $12 \%$ & $7 \%$ & $3 \%$ \\
\hline \multicolumn{7}{|c|}{ Panel B-Canada } \\
\hline Hourly Wages & \multicolumn{3}{|c|}{1992} & \multicolumn{3}{|c|}{2015} \\
\hline $\begin{array}{c}\% \text { of } \\
\text { minimum } \\
\text { wage }\end{array}$ & $0-->$ PT & $0-->$ FT & PT $-->$ FT & $0-->$ PT & $0-->$ FT & PT $-->$ FT \\
\hline $100 \%$ & $70 \%$ & $67 \%$ & $63 \%$ & $32 \%$ & $45 \%$ & $58 \%$ \\
\hline $125 \%$ & $76 \%$ & $58 \%$ & $41 \%$ & $42 \%$ & $41 \%$ & $40 \%$ \\
\hline $150 \%$ & $80 \%$ & $53 \%$ & $26 \%$ & $49 \%$ & $38 \%$ & $26 \%$ \\
\hline $200 \%$ & $67 \%$ & $47 \%$ & $27 \%$ & $45 \%$ & $34 \%$ & $23 \%$ \\
\hline
\end{tabular}

Notes: Part-time (PT) defined as working 20 hours a week, 52 weeks a year. Full-time (FT) defined as working 40 hours a week, 52 weeks a year. Each cell shows the participation tax rate on cash and near-cash universal state/provincial and federal transfers for a hypothetical single individual with no children moving out of work into employment with wages equivalent to the 2015 minimum wage (adjusted for inflation using the CPI-U). For the US, this example scenarios faced by a single individual living in Colorado. For Canada, this example illustrates scenarios for a single individual living in Ontario. See text for details. 
Appendix Figure 1: US budget constraint, cash and near-cash universal programs (2015\$)

Panel A: Single adult with no children, Colorado, 1992

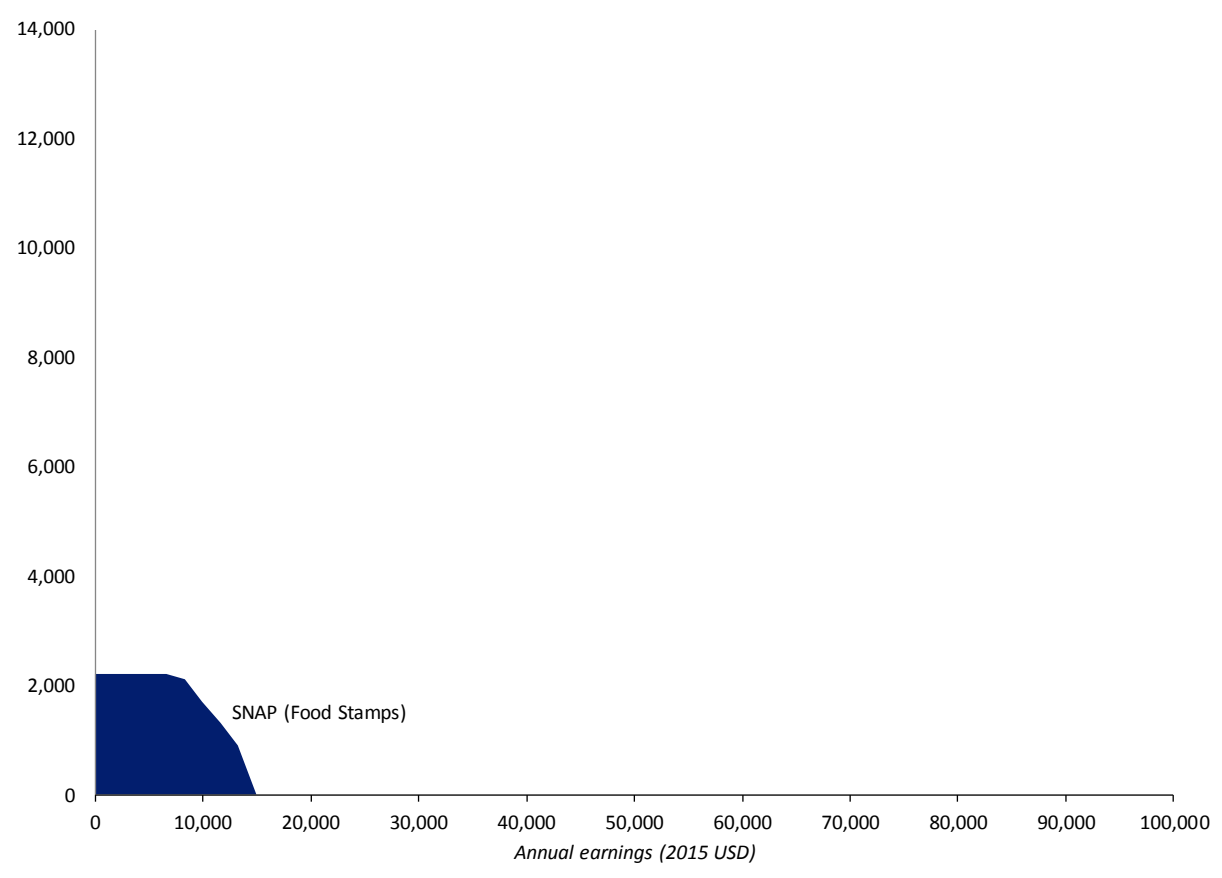

Panel B: Single adult with no children, Colorado, 2015

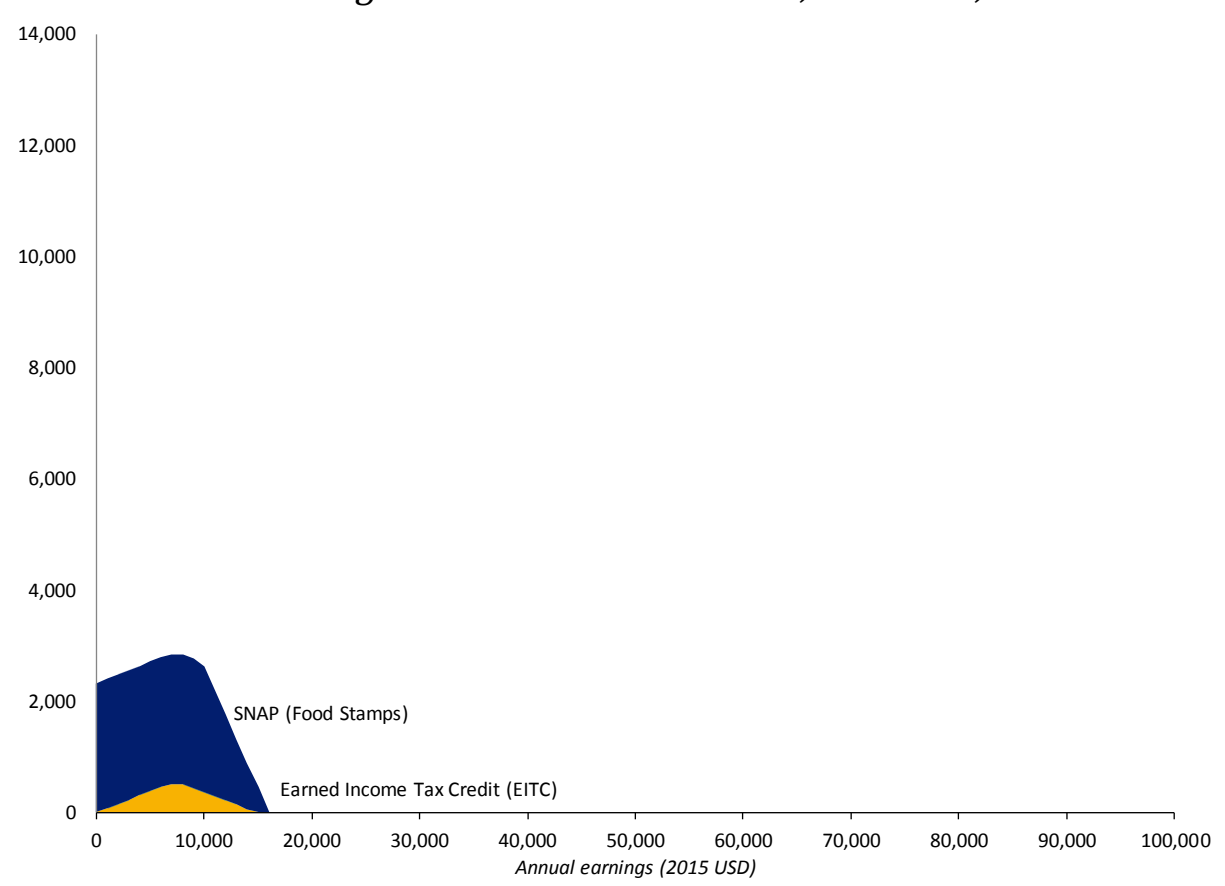

Notes: Estimated value of tax and transfer benefits for a single parent with two children living in Colorado. Program parameters from Internal Revenue Service and Tax Policy Center (EITC, CTC, Dependent Exemption, Child and Dependent Care Tax Credit) and Ways \& Means Green Book and Department of Agriculture (SNAP). Based on data from Steuerle and Quakenbush (2015). 
Appendix Figure 2: Canada budget constraint, cash and near-cash universal programs $(2015 \$)$

Panel A: Single adult with no children, Ontario, 1992

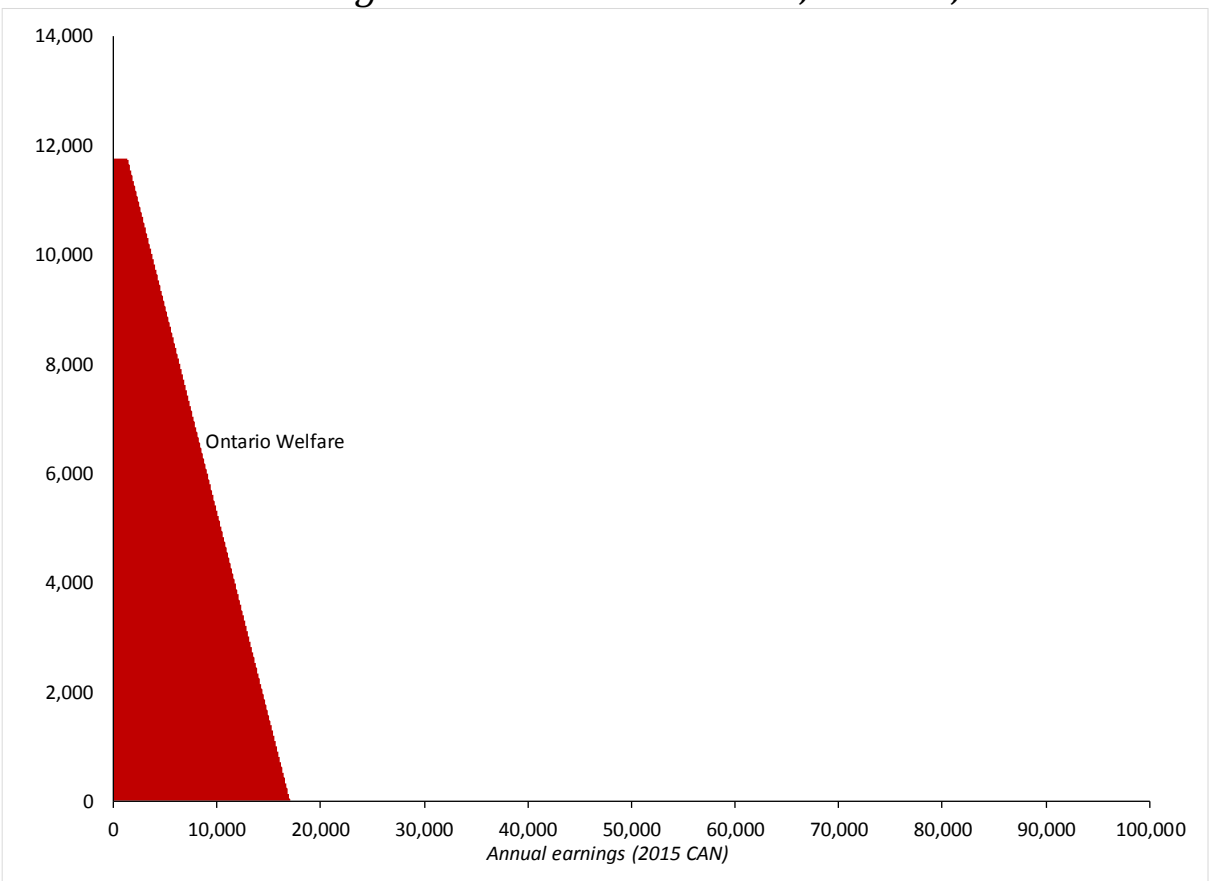

Panel A: Single adult with no children, Ontario, 2015

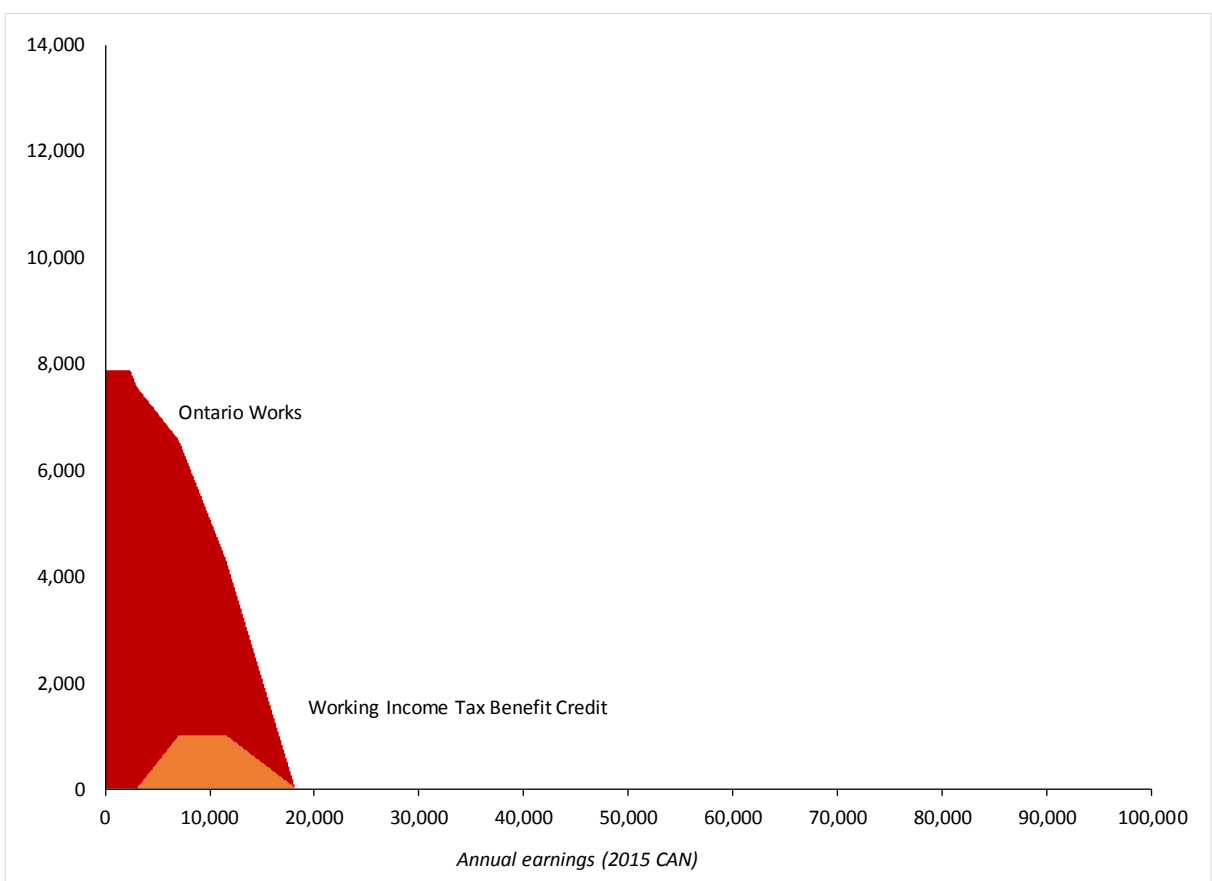

Notes: Estimated value of major tax and transfer programs for a single individual with no children in the province of Ontario in real (2015) CDN dollars. Program parameters from Department of Finance, Canada and the Ontario Ministry of Finance. 